NBER WORKING PAPER SERIES

\title{
PRESERVING HISTORY OR HINDERING GROWTH? THE HETEROGENEOUS EFFECTS OF HISTORIC DISTRICTS ON LOCAL HOUSING MARKETS IN NEW YORK CITY
}

\author{
Vicki Been
}

Ingrid Gould Ellen

Michael Gedal

Edward Glaeser

Brian J. McCabe

Working Paper 20446

http://www.nber.org/papers/w20446

\author{
NATIONAL BUREAU OF ECONOMIC RESEARCH \\ 1050 Massachusetts Avenue \\ Cambridge, MA 02138 \\ September 2014
}

We would like to thank Gerard Torrats-Espinosa for his exceptional research assistance. We also wish to thank Sara Lense and Paul Salama for their assistance in preparing and analyzing the data, and Rohan Jolly and Clint Wallace for their research on the law of historic designation and the policy controversies that accompany designation. We are grateful for suggestions and questions we received from participants in the 2011 and 2013 fall APPAM meetings, the 2013 AREUEA meetings, and Furman Center for Real Estate and Urban Policy brown bag lunch series. We would especially like to thank our conference discussants, Matthew Freedman and Claudia Sharygin. We are indebted to the Furman Center for Real Estate and Urban Policy at NYU for supporting this research, and to the Filomen D'Agostino and Max E. Greenberg Faculty Research Fund for support of Professor Been. Note that Professor Been worked on this project before she became Commissioner of Housing Preservation and Development in New York City. The views represented here are those of the authors and do not necessarily reflect those of the Federal Reserve Bank of New York or the Federal Reserve System. The views expressed herein are those of the authors and do not necessarily reflect the views of the National Bureau of Economic Research.

At least one co-author has disclosed a financial relationship of potential relevance for this research. Further information is available online at http:/www.nber.org/papers/w20446.ack

NBER working papers are circulated for discussion and comment purposes. They have not been peerreviewed or been subject to the review by the NBER Board of Directors that accompanies official NBER publications.

(C) 2014 by Vicki Been, Ingrid Gould Ellen, Michael Gedal, Edward Glaeser, and Brian J. McCabe. All rights reserved. Short sections of text, not to exceed two paragraphs, may be quoted without explicit permission provided that full credit, including (C) notice, is given to the source. 
Preserving History or Hindering Growth? The Heterogeneous Effects of Historic Districts on Local Housing Markets in New York City

Vicki Been, Ingrid Gould Ellen, Michael Gedal, Edward Glaeser, and Brian J. McCabe

NBER Working Paper No. 20446

September 2014

JEL No. A0,R0

\begin{abstract}
$\underline{\text { ABSTRACT }}$
Since Brooklyn Heights was designated as New York City's first landmarked neighborhood in 1965, the Landmarks Preservation Commission has designated 120 historic neighborhoods in the city. This paper develops a theory of heterogeneous impacts across neighborhoods and exploits variation in the timing of historic district designations in New York City to identify the effects of preservation policies on residential property markets. We combine an extensive dataset of residential transactions during the 35-year period between 1974 and 2009 with data from the Landmarks Preservation Commission on the location of the city's historic districts and the timing of the designations. Designation raises property values within historic districts, but only outside of Manhattan. In areas where the value of the option to build unrestricted is higher, designation has a less positive effect on property values within the district. Consistent with theory, properties just outside the boundaries of districts increase in value after designation. There is also a modest reduction in new construction in districts after designation.
\end{abstract}

\author{
Vicki Been \\ New York University School of Law \\ 40 Washington Square South, 314H \\ New York, NY 10012 \\ vicki.been@nyu.edu \\ Ingrid Gould Ellen \\ New York University \\ Robert F. Wagner Graduate School \\ of Public Service \\ 295 Lafayette Street \\ New York, NY 10012 \\ ingrid.ellen@nyu.edu \\ Michael Gedal \\ Federal Reserve Bank of New York \\ 33 Liberty Street \\ New York, NY 10045 \\ Michael.Gedal@ny.frb.org
}

\author{
Edward Glaeser \\ Department of Economics \\ 315A Littauer Center \\ Harvard University \\ Cambridge, MA 02138 \\ and NBER \\ eglaeser@harvard.edu \\ Brian J. McCabe \\ Georgetown University \\ 3520 Prospect St., NW - Suite 209 \\ Washington, DC 20057 \\ mccabeb@georgetown.edu
}




\section{Introduction}

In 1965, the New York City Landmarks Preservation Commission was created to formalize the channels through which historic properties were protected and preserved in New York City (Wood 2008). That same year, the Commission designated Brooklyn Heights as the city's first landmarked neighborhood, and has since designated 120 historic neighborhoods in the city. These districts range from the Upper East Side Historic District, encompassing more than 50 blocks (or parts thereof) on the east side of Central Park, to the recently-designated Perry Avenue Historic District, an agglomeration of just nine single-family homes in the Bronx.

The preservation of historic neighborhoods has been controversial in New York City and elsewhere. Preservation advocates argue that the market-driven process of urban development will not adequately protect a city's architectural heritage, as individual owners will not internalize the full benefit to society of historic preservation (Mourato \& Mazzanti 2002). Proponents argue that historic districts generate economic externalities, for the city as whole, both by increasing tourism and nurturing the city's art and culture (Rypkema 2005). To the extent that they create a common identity for neighborhood residents, the creation of unified historic neighborhoods could encourage the growth of community organizations and heighten social cohesion (Rose 1981). Preservation proponents worry that the political process may be stacked against historic, aesthetic, or cultural considerations, especially in cities increasingly subject to the pressure from the demands of property developers (Verrey \& Henley 1991).

Preservation critics, conversely, argue that preservationists are just another wellorganized lobby of incumbents opposing change. While many critics recognize the value of preserving historic structures and neighborhoods, they often contend that preservation policies unfairly restrict the rights of property owners. Property owners in historic districts are often subject to extensive regulatory hurdles that may discourage property owners from making improvements that would maximize the value of their property. In limiting development within historic districts, critics contend that these policies limit the supply of housing, driving the cost of housing beyond the reach of many residents and contributing to a larger crisis of affordability. Taken to the extreme, historic preservation could limit a city's ability to grow and adapt to the needs of an increasingly competitive global system of cities (Glaeser 2010).

As our theoretical model stresses, the impact of historic preservation is unlikely to be uniform across neighborhoods. Preservation has at least two offsetting effects on local property values. On the one hand, the designation of a historic district restricts the changes property 
owners can make to their buildings and prohibits demolition and redevelopment. This loss of flexibility - the forgone option to redevelop potentially at higher density levels - should lower land and property values, especially in high demand areas that are initially low density. On the other hand, designation can preserve the historic beauty - or amenity level — of a neighborhood and minimize the risks that new investment will undermine the distinctive character of the area. This effect should be larger in areas with architectural attributes that buyers and renters value, and in areas that have high density levels before preservation. The designation of a district also may increase demand by conferring a special status on properties in the district, or by restricting supply is demand is sufficiently inelastic.

The model predicts that preservation will not uniformly affect all neighborhoods. If demand for the location is high and heights are far below the allowable zoning cap, then the lost option value is large and land values should fall. If buildings are initially high or demand for the location is low, then the impact of preservation on prices is likely to be positive. Thus, we would expect that designation would have a more negative effect on property values in higher value neighborhoods with a greater share of buildings built at heights well below the allowable limits. By contrast, we would expect historic designation to have more positive impacts on property values in neighborhoods where buildings are generally already built to the heights allowed by zoning, and values are lower. Preservation should also provide more benefit to owners if the neighboring historic homes that are preserved by the district rules are more attractive and historically meaningful. The model also predicts that properties immediately outside districts are likely to receive many of the same benefits as properties within the district without the imposed restrictions, we expect to see surrounding properties increase in value after designation.

While expanding on current research on the price impact of historic designations, our study also explores the impact of historic designation on housing supply. In general, theory predicts that the rules accompanying designation will limit the amount of new construction activity that occurs in historic districts. We expect these effects to be felt more strongly when market demand is high and the underlying zoning is more lenient.

This paper evaluates how historic district designation affects both the prices of residential properties in New York City and reinvestment. In brief, we find that designation raises property values within historic districts, but only for the boroughs outside Manhattan. More generally, we find that designation decreases the value of properties in districts where the foregone option to 
redevelop is higher. Consistent with theory, we also find that properties just outside the boundaries of districts increase in value after designation. Finally, we find modest evidence of reduced construction activity in districts after designation.

\section{Theoretical Model: Historic Districts, Building and Land Prices}

What impact will a historic district designation have on welfare, construction, land prices and unit prices within a designated area? We now explore these questions with an economic model, which will guide our subsequent empirical work. We consider a city with a continuum of neighborhoods, each containing exactly one unit of land that is subdivided into a continuum of parcels. Within a neighborhood, parcels are assumed to be homogeneous, at least before any redevelopment occurs, so that all building are of height $\tilde{h}_{n}$ and aesthetic value $\tilde{\alpha}_{n}$. Ex post building heights are denoted $h_{n}$ and the ex post aesthetic value in the neighborhood is $\alpha_{n}$, the average aesthetic value in the neighborhood weighted by land area.

The total welfare associated with living in one of these neighborhoods, relative to a reservation locale elsewhere, equals non-aesthetic welfare, equal to $B_{n}^{j}$ which is specific to person and neighborhood, plus the local aesthetic value $\alpha_{n}$ plus the city-wide aesthetic value of $\delta \int_{i=1}^{N} \alpha_{i} d i$ or $\delta A$, the weighted average of the aesthetic amenity value for the entire city. Hence for person $\mathrm{j}$ the willingness to pay live in neighborhood n equals $B_{n}^{j}+\alpha_{n}+\delta \int_{i=1}^{N} \alpha_{i} d i$.

As aesthetics are at the heart of historic preservation, we focus more on the ephemeral notion of aesthetics than usual in housing economics, which more typically stresses the tangible sources of structural value. Moreover, since preservationists often care passionately about neighborhoods other than their own, we allow a citywide aesthetic effect. The aesthetic quality of the neighborhood, and the city, will change with redevelopment and since neighborhoods may be incompletely redeveloped, they may also end up being heterogeneous.

The non-aesthetic value is meant to include the economic returns from living in the city and the commuting costs in each neighborhood. We initially assume this value is constant across individuals and denoted $B_{n}$, but later allow for individual heterogeneity. In the case of homogeneous preferences (but not heterogeneous preferences), a Henry George theorem applies (Arnott and Stiglitz, 1979) and property values across the city as a whole are the most sensible measure of welfare. 
If the price of housing in neighborhood $\mathrm{n}$ is denoted $p_{n}$, then the spatial equilibrium requires that this must equal $B_{n}+\alpha_{n}+\delta A$. Neighborhoods are assumed to small relative to the city and buildings are assumed to be arbitrarily small relative to a neighborhood. As such, when making construction decisions, builders will not automatically internalize the impact of lowering aesthetics on others.

Since willingness to pay does not rise with building aesthetics, only with neighborhood aesthetics, firms will provide the minimum possible aesthetic level given current regulations and technology, which equals $\alpha_{0}$. The model could be easily changed so the homebuyers did care about the aesthetics of their building, as long as these were homogeneous across individuals, and in that case $\alpha_{0}$ could be interpreted as the optimal aesthetic value of new building given buyers' preferences.

If a share, $s_{n}$ of the neighborhood's land area is re-developed then $\alpha_{n}=s_{n} \alpha_{0}+$ $\left(1-s_{n}\right) \tilde{\alpha}_{n}$, where $\tilde{\alpha}_{n}$ represents the historic amenity value of the area. The cost of redeveloping a parcel is captured by a convex function $\mathrm{c}(\mathrm{h})$, where $\mathrm{h}$ is the height of the new building. We also assume that $\bar{h}_{n}$ is the legal maximum of new building heights in the neighborhood. We can now define a redevelopment equilibrium:

Definition: A redevelopment equilibrium exists if for all parcels that can be legally re-developed, redevelopment occurs if and only if $\left(B_{n}+\alpha_{n}+\delta \int_{i=1}^{N} \alpha_{i} d i\right)\left(\operatorname{Min}\left(h_{n}^{*}, \bar{h}_{n}\right)-\tilde{h}_{n}\right) \geq c\left(h_{n}^{*}\right)$, where $B_{n}+\alpha_{n}+\delta \int_{i=1}^{N} \alpha_{i} d i=c^{\prime}\left(h_{n}^{*}\right)$, where $\alpha_{n}=s_{n} \alpha_{0}+\left(1-s_{n}\right) \tilde{\alpha}_{n}$ and $s_{n}$ equals the share of each neighborhood that is redeveloped. Redevelopers earn zero profits.

The definition stresses that redevelopment must be optimal on both the intensive and extensive margin. Builders will erect towers up to the height where the marginal benefit of extra space, captured by the price, equals the marginal cost of building up, or up to the legal maximum. They will redevelop parcels to the point where the gain in value from more height on that parcels offsets the cost of redevelopment including land.

Treating city-wide redevelopment behavior as given, we now focus on a particularly neighborhood and let $h_{0}^{*}$ refer to the optimal height if the entire neighborhood is redeveloped and $\alpha_{n}=\alpha_{0}$. We define let $h_{\max }\left(\tilde{\alpha}_{n}\right)$ define the maximum value of height at which marginal 
development covers costs. ${ }^{2}$ This cutoff value $h_{\max }\left(\tilde{\alpha}_{n}\right)$ is increasing with $\tilde{\alpha}_{n}$ because the benefits of adding more density are higher when the neighborhood is nicer. The following Lemma characterizes the possible equilibrium outcomes in a neighborhood, assuming that the height restriction does not bind:

Lemma 1: If $\tilde{\alpha}_{n}>\alpha_{0}$, then there will be partial redevelopment if and only if $\tilde{h}_{n}<h_{\max }\left(\tilde{\alpha}_{n}\right)$ and there will be total redevelopment if and only if $h_{\max }\left(\tilde{\alpha}_{n}\right)>h_{0}^{*}-\frac{c\left(h_{0}^{*}\right)}{B+a_{0}+\delta A}>\tilde{h}_{n}$.

If $\tilde{\alpha}_{n}<\alpha_{0}$, then $h_{\max }\left(\tilde{\alpha}_{n}\right)<h_{0}^{*}-\frac{c\left(h_{0}^{*}\right)}{B+a_{0}+\delta A}$, and if $\tilde{h}_{n}<h_{\max }\left(\tilde{\alpha}_{n}\right)$ then there will be total redevelopment, if $\tilde{h}_{n}>h_{0}^{*}-\frac{c\left(h_{0}^{*}\right)}{B+a_{0}+\delta A}$ there will be no redevelopment, and if $h_{\max }\left(\tilde{\alpha}_{n}\right)<$ $h n<h 0 *-c h 0 * B+a 0+\delta A$ then total redevelopment and no redevelopment are both possible outcomes. There is also a mixed redevelopment equilibrium, which is unstable according to standard arguments.

This lemma's implications for redevelopment behavior are illustrated in Figure 1. Redevelopment is shaped by the combination of initial height levels and initial amenity levels. If $h_{0}^{*}-\frac{c\left(h_{0}^{*}\right)}{B+a_{0}+\delta A}<\tilde{h}_{n}$, so an area has taller buildings, then there is less benefit from adding more density. Partial redevelopment will be optimal, in this case, only if the initial neighborhood quality is high enough so that initial prices are high enough to pay for redevelopment. In this case, more redevelopment will lower neighborhood quality and eventually cause redevelopment to stop.

If $h_{0}^{*}-\frac{c\left(h_{0}^{*}\right)}{B+a_{0}+\delta A}>\tilde{h}_{n}$, then initial heights are low, and total redevelopment is always one possible equilibrium. If initial neighborhood quality is low, then there is a second equilibrium with no redevelopment. This multiple equilibrium situation captures the possibility that some neighborhoods may remain blighted for years and then quickly "tip" with rapid redevelopment. If initial neighborhood quality is higher, then redevelopment will always occur and it will always be complete, possibly even destroying value. Somewhat paradoxically, as we will discuss later,

\footnotetext{
${ }^{2}$ Technically, $h_{\max }\left(\tilde{\alpha}_{n}\right)$ is defined by $\left(B_{n}+\tilde{\alpha}_{n}+\delta A\right)\left(\tilde{h}_{n}^{*}\left(\tilde{\alpha}_{n}\right)-h_{\max }\left(\tilde{\alpha}_{n}\right)\right)=c\left(\tilde{h}_{n}^{*}\left(\tilde{\alpha}_{n}\right)\right)$ and $\left(B_{n}+\tilde{\alpha}_{n}+\delta A\right)=$ $c^{\prime}\left(\tilde{h}_{n}^{*}\left(\tilde{\alpha}_{n}\right)\right)$ and $h_{0}^{*}$ satisfies $B_{n}+\alpha_{0}+\delta A=c^{\prime}\left(h_{0}^{*}\right)$.
} 
it can be optimal for the same government to force redevelopment in some neighborhoods while preventing it in others. Changes in these parameter spaces are illustrated in Figure 1, which shows the core areas predicted by the model.

Changes in the overall level of demand for the city will shift the parameter spaces. As the city as a whole becomes more attractive, total redevelopment becomes an equilibrium outcome for initially taller neighborhoods. Holding height constant, redevelopment becomes more common as demand for the city as whole rises.

What would height regulations do to redevelopment behavior? A binding height limit reduces the profits from redevelopment, which means the maximum height threshold for total redevelopment of an area falls. The minimum amenity level for marginal redevelopment efforts rises as height limitations become more stringent. If absolute bans present a sure way to reduce redevelopment, height limits present an only slightly less effective means of accomplishing that aim.

If $\alpha_{0}<\tilde{\alpha}_{n}$, then parcel owners will always benefits if their neighbors are subject to restrictions, as long as they are not. The restriction keeps aesthetic quality high, while still allowing them to build. This logic lies behind our empirical analysis of buffer zones, which we assume are essentially part of the same neighborhood even though they are not bound by the same rule.

Proposition 1 solves the social planner's problem for redevelopment of a neighborhood, internalizing the social effects on the city as a whole. If city has total power about how much to redevelop and where, what redevelopment should take place? Notably, in this case, there is no role for height restrictions on new development, so we will not discuss them. Proposition 2 tackles the more realistic question of asking in which areas should redevelopment be banned if the city cannot control the amount of redevelopment that occurs if it is allowed.

Proposition 1: If $\tilde{\alpha}_{n}>\alpha_{0}$, then total redevelopment is optimal only if heights are below a threshold that is lower than $h_{0}^{*}-\frac{c\left(h_{0}^{*}\right)}{B+a_{0}+\delta A}$ and that threshold is falling with $\tilde{\alpha}_{n}$, and partial redevelopment will be optimal only if heights are below a threshold that is lower than $h_{\max }\left(\tilde{\alpha}_{n}\right)$ and that threshold is also falling with $\tilde{\alpha}_{n}$. If $\tilde{\alpha}_{n}>\alpha_{0}$, then optimal levels of redevelopment will always be lower than the competitive level of redevelopment. 
If $\tilde{\alpha}_{n}<\alpha_{0}$, total redevelopment is optimal as long as heights are below a threshold that is greater than $h_{0}^{*}-\frac{c\left(h_{0}^{*}\right)}{B+a_{0}+\delta A}$, and that threshold is also falling with $\tilde{\alpha}_{n}$.

This proposition captures the time path of post-war housing policy in many American cities. In the immediate post-war period, the policy concern was blight: the existence of many neighborhoods that had low heights and low levels of aesthetic values. Redevelopment was perceived as being socially optimal but not privately optimal, at least for small scale developers. In some cases, the problem appears to have been coordination, as evidence by the role for that very large developers, like Metropolitan Life, played in shifting entire communities. In other cases, there may have been city-wide externalities that were internalized by the action.

Yet over time, redevelopment claimed areas with higher and higher aesthetic levels, particularly in areas with high demand for density, like the old Penn Station. This led to a switch in public policy from working on market failure number one (too little redevelopment of low amenity areas) to market failure number two (too much redevelopment of high amenity areas).

If the government cannot control heights, but only has the freedom to restrict or not restrict the overall condition for restricting development is $\left(B_{n}+\alpha_{0}+\delta A\right)\left(h_{0}^{*}-\tilde{h}\right)-c\left(h_{0}^{*}\right)<$ $\left(\tilde{\alpha}-\alpha_{0}\right)(\tilde{h}+\delta S)>0$, which can be operationalized as a criterion for allowing redevelopment. The ex post price times the change in heights minus the cost of new construction must be greater than the change in local values due to redevelopment times the old height plus the city-level externality of the change. The total externality is $\left(\tilde{\alpha}-\alpha_{0}\right)(\tilde{h}+\delta S)$.

Restrictions on redevelopment only make sense in areas where $\tilde{\alpha}_{n}>\alpha_{0}$. If initial height levels are moderate enough so that redevelopment is partial, then the property owners who don't redevelop are worse off (their unit prices have fallen), but since all property owners must be indifferent between redeveloping or not, then all property owners are worse off. This implies that if redevelopment is partial in these settings, then a ban is better than the unfettered market, although it could well be that a more limited redevelopment is better than either of those outcomes. In settings, where unfettered development is complete, then it is unclear whether banning development is better than total redevelopment.

Banning redevelopment is also less attractive in areas with higher density levels. The shorter the initial buildings, the higher the minimum amenity cutoff for preserving a district 
should be. The optimal strategy also depends on the state of the city. A more attractive city means that the level of redevelopment should be greater.

Our next proposition guides our empirical work, which focuses on the price and quantity impacts of preservation district. We now ask what the a ban on redevelopment will do local land prices, housing unit prices, and quantities of new construction, as a function of initial height levels and amenity levels:

Proposition 2: If redevelopment would not have happened anyway, because initial heights are high, than preservation districts have no impact. If initial heights are lower and $\tilde{\alpha}_{n}<\alpha_{0}$, then preservation districts will reduce construction, units prices and total real estate value. Preservation will reduce unit prices and total real estate value by less if if initially amenity levels are higher; preservation will decrease total real estate values less if initial heights are higher. If $\tilde{\alpha}_{n}>\alpha_{0}$ and $h_{\max }\left(\tilde{\alpha}_{n}\right)>\tilde{h}_{n}$, then preservatio will reduce construction and raise unit prices, especially if $\tilde{\alpha}_{n}$ is higher. If $h_{\max }\left(\tilde{\alpha}_{n}\right)>\tilde{h}_{n}>h_{0}^{*}-\frac{c\left(h_{0}^{*}\right)}{B+a_{0}+\delta A}$, then the negative impact on the district construction will be higher if initial heights are lower or amenities are lower, and total real estate values will always be increased by the district. If $\tilde{h}_{n}<h_{0}^{*}-\frac{c\left(h_{0}^{*}\right)}{B+a_{0}+\delta A}$, then the preservation can cause total real estate values to fall.

Preservation districts will raise unit prices if the initial aesthetic level of the area is higher than the typical level for new construction, but will lower unit prices otherwise. This statement looks only at the value of units for use, and doesn't consider that unit prices also capture the option of rebuilding, which is better captured by our comparative statics on total real estate value. Still, if initial aesthetics are sufficiently low, preservation also destroy total value. If initial aesthetic levels are higher, preservation can increase value, both for the unit and total real estate. Preservation is most likely to destroy value when initial heights are sufficiently low, at least relative to the maximum build-out that is possible in New York.

It is also true that the districts are more likely to reduce value in areas that have a nonaesthetic appeal, for those are the areas where added density is most likely to be value. Overall, there are a range of neighborhoods for which local property values would be higher than those that would solely maximize local land values. As such, for higher amenity areas preservation increases property values, but for low amenity areas, preservation reduces property values. The overall effect becomes an empirical matter. 


\section{Heterogeneous Preferences for Neighborhoods}

We now introduce individual heterogeneity, but simplify along other dimensions. We assume that there is a supply of individuals with heterogeneous tastes for living in the neighborhood. We will not address cross neighborhood tastes and assume that all the inhabitants of one neighborhood are deciding only between the reservation locale and that particular area. The term $B_{n}(\mathrm{~S})$, now refers to the preference of the marginal resident of the city, and it satisfies $S=\int_{B_{n}^{j} B_{n}(S)}^{\infty} q\left(B_{n}^{j}\right) d B_{i}$, where $q\left(B_{n}^{j}\right)$ refers to the number of individuals with preference level $B_{i}$. The overall return from residing in an area still equals $B_{n}(S)+\alpha_{n}+\delta A$. We now assume that there are only two possible heights $\underline{h}$ and $\bar{h}$. There are $N_{\text {new }}$ new neighborhoods, with amenity levels $\quad \alpha_{0}$, and height $\bar{h}$. There is a distribution of old neighborhoods which all have height $\underline{h}$ and are characterized by a density of amenity levels $f(\alpha)$. The cost of redeveloping is "c" per land unit which increases the height from $\underline{h}$ to $\bar{h}$. We assume that $\left(B_{n}(S)+\alpha_{0}+\delta A\right)(\bar{h}-\underline{h})>$ $c$, so total redevelopment is always an equilibrium outcome for every neighborhood, and partial

redevelopment is never an equilibrium outcome without government interference. If $\alpha>\frac{c}{\bar{h}-\underline{h}}-$ $B_{n}(S)-\delta A$, then redevelopment is the only free market equilibrium outcome.

We consider two alternative welfare functions. The first maximizes solely the property values in the city; the second maximizes global welfare. The difference is whether the city internalizes the welfare of marginal residents.

Proposition 3: Whether the government internalizes the welfare of its citizens or just property values, redevelopment will only be allowed into neighborhoods with amenity levels that fall below an amenity threshold. In either case, the threshold will be rising with $\alpha_{0}$ and $\bar{h}$ and falling with $\mathrm{c}$ and $\underline{h}$. If the government maximizes property values the threshold will also be falling with $q\left(B_{n}(S)\right)$, but not if the government maximizes property values plus resident welfare. If the government maximizes resident welfare the threshold will be higher. If the government can set the level of development, the desired level will always be lower, if the government does not internalize the welfare of its residents. 
This perturbation of the model examines the gap in the interests between property owner interests and the interests of residents. Property owners benefit more from preservation than renters because preservation pushes property values up for two reasons. Values rise because of rising amenities, which is a benefit shared by renters, and value rise because supply is restricted, which does nothing to help renters. As such, a government that maximizes total property values will typically be more restrictive than a government that maximizes total welfare, both in mandating too much preservation and in allowing too little development, when it controls that amount of redevelopment. Essentially, this proposition emphasizes that preservation districts, like all building restrictions, can push prices up by restricting supply in a monopolistic fashion that does not enhance welfare.

\section{Preserving Historic Neighborhoods in New York City}

Nowhere in the United States have the debates about historic preservation received greater attention than in New York City. The creation of the city's Landmarks Preservation Commission (LPC) in 1965 followed several decades of activism in New York City to preserve historically valuable landmarks and neighborhoods (Wood 2008). Threats to the neighborhood of Brooklyn Heights from the construction of the Brooklyn-Queens Expressway, along with the demolition of the Beaux Arts Penn Station, galvanized the creation of the Commission. In late 1965, the Commission designated Brooklyn Heights as the city's first historic district. Within five years, the Commission designated fourteen additional historic neighborhoods across the city, including Greenwich Village in Manhattan, Cobble Hill in Brooklyn, and Mott Haven in the Bronx. Between 1965 and 2009 - the final year of data available at the time of this analysis the LPC designated exactly one hundred historic neighborhoods in New York City, and approved thirteen extensions to the original boundaries of historic districts. By 2012, the LPC has designated another 20 districts.

As Table 1 shows, nearly sixty percent of historic districts are located in Manhattan, but the LPC has designated districts in each of the five boroughs. Slightly more than 25 percent of districts are located in Brooklyn, and slightly fewer than 10 percent of historic districts are located in the Bronx. In total, 4.8 percent of residential units in New York City are located within historic districts, and 11.8 percent of residential units in Manhattan. ${ }^{3}$ Since 1965, the

\footnotetext{
${ }^{3}$ Analysis from the Furman Center (see Been et al., 2011)
} 
amount of land included in historic districts has grown faster in the outer boroughs than in Manhattan. Table 1 also shows the designations of historic district by decade. It confirms a relatively stable pace of designation since the establishment of the Landmarks Preservation Commission, with an uptick in landmark designations during the 2000s.

The historic districts we study range substantially in size and scope. Some of the smallest districts encompass only a handful of lots, while many of the larger districts include scores of blocks encompassing some of the city's most revered neighborhoods. The Sniffen Court Historic District, located on the east side of Manhattan, consists of ten Romanesque Revival stables, making it one of the smallest districts in the city. By contrast, the Upper East Side Historic District includes portions of more than fifty blocks, encompassing much of what is colloquially known as the Upper East Side. The recent designation of the Perry Avenue Historic District as the city's one-hundredth historic district underscores the City's interest in designating a range of neighborhood types. Located in the Bedford Park neighborhood of the Bronx, the Perry Avenue Historic District includes nine historic homes dating back to the early twentieth century.

\section{The Process of Designating a Historic District}

Although the designation of historic districts in New York City is clearly not exogenous, it is not always driven by neighborhood property owners. In many cases, historic preservation advocates are heavily involved. The process of designating a historic district involves several steps, which are described in detail in Appendix B. ${ }^{4}$ In brief, proposals from community leaders and preservation advocates usually trigger the process, which then involves review of such "requests for evaluation" by a committee that includes the Chair of the LPC and various staff members. That committee can then elect to send a particular proposal on to the full LPC, and if so, the LPC first decides, in a public meeting, whether to "calendar" the proposal. If the proposal is calendared, the LPC then holds a public hearing, at which the LPC staff present the proposal, and property owners and other interested parties are given an opportunity to testify or

\footnotetext{
${ }^{4}$ The authority for the following description is provided in Appendix A, and includes the N.Y.C. Charter $\S 3020$; N.Y.C. Admin. Code $\S \S 25-302,25-303$, and 25-313; Rules of the City of New York, Title 63, Landmarks Preservation Commission Rules 1-02, 1-01 (July 2003); NEW YORK CITY LANDMARKS PRESERVATION COMMISSION, FAQs: The Designation Process, http:/www.nyc.gov/html/lpc/html/faqs/faq_designation.shtml (last visited October 13, 2011); and HistoriC DistriCTs CounCIL, Preserving Your Historic Neighborhood: New York City Designation Process, http://www.hdc.org/preservingnyc.htm (last visited October 12, 2011).
} 
submit written comments. Should the LPC choose to designate a district, which it almost always does, the designation becomes effective immediately, but the LPC must file a "designation report" with the City Council, the City Planning Commission (CPC), and other city agencies for comment. The CPC is required to hold another public hearing on the proposed district, and to file a report on the proposal with the City Council. The City Council then may modify or reject the proposed district by majority vote. The mayor may veto a modification or rejection of the LPC's decision, and only a vote of two thirds of the City Council will over-ride the veto.

\section{The Restrictions Designation Imposes}

The designation of a historic district triggers a special review process for requests for building construction and modification that may affect the level of investment and the value of properties in historic districts. In brief, if the owner of a building within a historic district wants to make any repairs or improvements to her building, the owner must first secure the same alteration permit from the Department of Buildings (DOB) that would be required for any construction work on a building anywhere in the city that goes beyond "ordinary" repairs and maintenance. ${ }^{5}$ In addition to obtaining permits from the Department of Buildings, the owner of property within a historic district must request and receive one of three determinations from the Landmarks Preservation Commission: (1) a "permit for minor work," (2) a "certificate of no effect," or (3) a "certificate of appropriateness." At the extreme, if a certificate of appropriateness is required, the owner's request will be the subject of a public hearing, and the LPC will consider how the proposed work will affect the exterior architectural features of the building, and "the relationship between the results of such work and the exterior architectural features of other, neighboring improvements" in the historic district. ${ }^{6}$ The approval process is described in detail in Appendix C.

In addition to requiring approval for alteration work that the property owner wants to perform, the LPC imposes an affirmative obligation that the owners of property within historic districts maintain and repair "all exterior portions" of the buildings, as well as all interior

\footnotetext{
${ }^{5}$ In New York City, the Department of Buildings issues three types of alteration permits: A1 permits are issued for alterations which require a new certificate of occupancy, including converting a single-family home into a multifamily residence; A2 permits are issued for multiple types of work (e.g., plumbing and construction), but do not require a certificate of occupancy; and A3 permits are issued for a single type of work that does not involve an amendment to the certificate of occupancy.

${ }^{6}$ N.Y.C. Admin. Code $\S 25-307(b)(1)$.
} 
portions which, if not maintained, may "cause the exterior portions" to "deteriorate, decay or... fall into a state of disrepair." There is little evidence that this requirement is strictly enforced, however.

\section{Empirical Approaches}

Identifying the effect historic district designations have on residential property values is methodologically challenging, as the selection of neighborhoods for historic designation is not random. It is possible - even likely - that the characteristics of properties located in neighborhoods designated as historic districts differ from properties in other neighborhoods in unmeasured ways. For example, properties located in historic districts could include ornamentation or other architectural features not captured in our hedonic regression analyses. If so, we should be concerned that location within a historic district is actually picking up unobserved property characteristics, rather than any effect of designation itself.

Further, trends in market conditions in neighborhoods designated as historic districts may differ from those in other neighborhoods. For example, residents may put more pressure on officials to designate their neighborhoods as historic districts when their property values are rising. If so, then any association between designation and property value appreciation may simply reflect these underlying trends and not be attributable to the designation itself. Conversely, preservation officials may believe that designating areas that are in need of revitalization as historic districts will help promote investment in those neighborhoods (or will help protect the city's investment in those areas). In both these situations, any association between designation and changes in property values may reflect underlying trends in demand rather than the effects of the designation itself.

Finally, the designation of a historic district may be accompanied by a variety of other changes that may affect property values. In many jurisdictions, for example, designation entitles the property owner to tax subsidies or reductions or waivers of fees (Econsult 2010). Those changes may offset or otherwise confound the effects that the designation itself may have on property values.

Most efforts to evaluate the impact of historic district designations on property values use standard hedonic price regression, controlling for basic structural attributes of a property and

${ }^{7} I d$. 
neighborhood characteristics. These hedonic analyses of historic districts generally suggest that location within a historic district is associated with a premium on property values (Ford 1989; Liechenko, Coulson \& Listokin 2001; Coulson and Lahr 2005; Mason 2005; Noonan 2007; Gilderbloom, Hanka and Ambrosius 2009; Carruthers, Clark and Tealdi 2010; Rypkema and Cheong 2011). One such study focuses on some Brooklyn neighborhoods between 1974 and 2002, reporting higher mean sales prices within historic districts (Treffeisen 2003).

Many hedonic analyses of the price effects of historic districts rely on cross-sectional data (or do not have access to prices of properties in districts before designation), and as such, cannot control for unmeasured differences between properties inside and outside of districts. The few recent studies that use longitudinal data find that designation has a negligible or even negative effect on property values. For example, a recent longitudinal analysis of historic districts in Boston indicates that historic districts depress prices (Heintzelman and Altieri 2011), suggesting that restrictions imposed on property owners outweigh the benefits of historic districts. Similarly, in a recent study of historic conservation areas in England, Ahlfeldt, Holman and Wendland (2012) find that prices are generally higher within conservation areas, but that designation itself fails to lead to any statistically significant boost in values. ${ }^{8}$ Finally, Noonan and Krupka (2011), after instrumenting for historic district designations, find that designation leads to a significant decline in prices.

Our paper extends previous research in several ways. First, following our model, we test for heterogeneous impacts across markets, which is made possible by New York's large number and variety of historic districts. Second, our dataset contains far more property sales transactions than earlier studies, relying on more than one million residential property sales in New York City. With access to such a large longitudinal data set, we are able to estimate a difference-indifference regression model to weed out pre-existing differences between properties located in historic districts and those outside. Further, the 35-year time-span of our data enables us to observe property sales and permitting activity decades after designation, allowing us to make claims about the long-term implications of historic district designations. Third, we study how the designation of historic districts affects the sales prices of properties that are located just outside a

\footnotetext{
${ }^{8}$ Of course, the rules governing historic districts in England differ from those governing districts in the United States.
} 
district. ${ }^{9}$ Finally, we study the impact historic district designation has on new construction activity, thus providing a fuller account of how districts shape local housing markets.

\section{Data and Methods}

Our analysis includes two components: the impact of historic designation on new housing construction within districts and the impact of designation on the sales price of residential properties across different neighborhoods. We outline the data and methods for each below.

\section{Data}

The first part of our analysis examines the construction of new units in historic districts. For this portion of the analysis, we restrict the sample to lots in census tracts that included at least one parcel within a historic district as of 2009. (We exclude districts designated earlier than 1990.) For each historic district, we define the area to include all lots located within the census $\operatorname{tract}(\mathrm{s})$ in which the historic district is located. Furthermore, we divide each historic district area into two zones: properties that are part of the historic district itself (district zone), and those located just outside the district but still within the same census tract (bordering zone). To calculate the number of new units created in each of the zones in our sample, we rely on information reported on building age in 2009 tax assessment data from the Real Property Assessment Database (RPAD) described below. Specifically, we create a longitudinal dataset, which records the number of new units constructed annually between 1990 and 2009, separately for each historic district itself and for the set of properties in its bordering zone.

Next, to estimate the impact of historic district designations on residential sales prices in New York City, we combine several administrative datasets. First, we use data on all residential property transactions in the city between 1974 and 2009. We limit the sample to arms-length sales. Furthermore, the analysis of sales data is restricted to the 32 community districts in New York that contained at least one lot in a historic district by 2009. Second, we merge the residential property transactions data with annual cross-sections of the Real Property Assessment Database (RPAD), an administrative data set gathered for the purpose of assessing property taxes. RPAD contains such property characteristics as lot size, building age, square footage and

\footnotetext{
${ }^{9}$ Noonan and Krupka (2011) come the closest to studying such border effects. They examine whether property values rise with the proportion of properties in block-group that are in a historic district. We are able to measure such border effects more precisely, using GIS.
} 
building classification. We match each transaction to property characteristics from the closest available year in RPAD. ${ }^{10}$

Although RPAD includes many characteristics of individual residential properties, it does not indicate whether a property is located within a historic district. For that information, we rely on the Primary Land Use Tax Lot Output (PLUTO) data. The PLUTO dataset includes one record for each tax lot in New York City. It includes an indicator identifying whether the lot is located within a historic district, allowing us to differentiate residential property transactions that occur within and outside of historic districts. Because PLUTO includes the name of the historic district, we are able to match historic districts to their date of designation using administrative data from the Landmarks Preservation Commission. Thus, we can identify whether residential property transactions within a district occur before or after the designation of the historic district. Using GIS methods, we are also able to identify properties that lie within 250 feet of a historic district boundary (buffer properties). For the properties in our study, Table 2 compares the characteristics of properties that were located within a historic district by the end of our study period (2009) with those located outside of historic districts.

To test for heterogeneity in impacts in neighborhoods where redevelopment is more valuable, we rank all community districts in our sample based on a series of measures that capture the value of redevelopment. For each of these measures, we create an indicator variable to identify properties located in community districts that fall above the median district in the sample. By interacting this dummy variable with the set of historic district variables in our model, we are able to test whether impacts vary by neighborhood. For these tests, we rank community districts using five measures. The first is average maximum floor-area ratio (FAR), calculated as maximum residential square footage permitted by zoning regulations divided by the total area of land zoned for residential use, both as of 2003. This measure reports, on average, the amount of residential building space that can be constructed on a square foot of land. The second measure is average unused FAR, which equals the aggregate maximum residential square footage permitted by zoning regulations minus the actual square footage of all residential buildings that existed as of 2003, divided by the total area of land zoned for residential use as of

\footnotetext{
${ }^{10}$ The earliest available year of RPAD is 1990 . As a result, property characteristics for residential sales before 1990 are matched to property characteristics in the 1990 version of RPAD. But most of the characteristics are relatively fixed and should not change much over time.
} 
2003. ${ }^{11}$ Third, we measure the ex ante value of newly built housing in the community district: specifically, the median price per square foot in buildings that were no more than 10 years old at the time of sale, using information from sales occurring 1974-1990. Our fourth measure is the ex ante dollar value of maximum FAR, which is simply average maximum FAR in the community district (measure 1) multiplied by the past value of new housing (measure 3). The fifth and final measure is the dollar value of unused FAR, which is the product of average unused FAR (measure 2) and the value of new housing (measure 3).

\section{Methods}

New Construction Analysis

To estimate impacts on new construction activity, we estimate a difference-in-difference model in which the dependent variable captures the number of new units built in zone $\mathrm{z}$ in area a in year t. As discussed above, each historic district area contains two zones: the "district" zone (properties within a district as of 2009) and the "bordering" zone (properties outside the district but within a census tract that includes a parcel in the district). Specifically, we estimate the following equation:

$$
N U_{z a t}=\alpha+\gamma_{a} W_{a}+\delta_{t} I_{t}+\theta H D_{z}+\rho \text { Post }_{a t}+\psi H D_{-} \text {Post }_{z a t}+\varepsilon_{z t},
$$

where $N U_{z a t}$ measures the number of new units constructed in zone $\mathrm{z}$ in area a in year $\mathrm{t} ; W_{a}$ is a set of historic district area fixed effects; $I_{t}$ is a set of year fixed effects; $H D_{z}$ is a dummy variable indicating whether the zone is a historic district (the comparison group therefore consists of properties located in the same historic district area, but in the bordering zone); Post $_{a t}$ is a dummy variable that captures whether the particular historic district associated with area a has been designated; and HD_Post $t_{\text {zat }}$ is an interaction between the HD dummy and the Post dummy. The key coefficient is that on the interaction term, which will capture the average difference between the change in the number of new units constructed in districts after designation and the change taking place in the bordering zone. We assume that absent designation, construction

\footnotetext{
${ }^{11}$ Ideally, we would like to measure FAR as of the time directly preceding the beginning of our sample period. However, existing data sources do not permit calculation of FAR prior to 2003. We calculate FAR measures using the 2003 PLUTO database, which reports several key pieces of information at a property level: lot area, maximum FAR permitted by zoning, and building square footage.
} 
activity would have increased by the same amount as it did in the bordering zones. In an alternative specification, we also include variables to capture the 250 -foot buffer zone surrounding the district, and thus the comparison area becomes parcels in bordering zones that are both outside the district and outside the buffer zone.

\section{Price Analysis}

To identify the impact historic district designation has on prices, our basic approach is to compare prices of properties in historic districts to prices of comparable properties that are outside the boundaries of a district, but still located in the same neighborhood (census tract). Then we examine whether the magnitude of this difference changes after the formal designation of the historic district - and changes in ways that aren't captured by broader neighborhood trends in prices. This approach weeds out any systematic, baseline differences between the properties chosen for designation and other properties around the city. It also allows us to disentangle the specific effects of the historic designation from the many other changes occurring across neighborhoods in the city.

We estimate a hedonic regression of the price of residential property using the following model:

$$
\ln P_{i c d t}=\alpha+\beta X_{i t}+\gamma_{c} W_{c}+\delta_{d t} I_{d t}+\theta H D_{i t}+\varepsilon_{i t}
$$

where $\ln P_{\text {icdt }}$ is the $\log$ of the sales price per unit of property i in census tract $\mathrm{c}$, in community district $\mathrm{d}$, and in quarter $\mathrm{t}$; $X_{i t}$ is a vector of property-related characteristics, including the building age, square footage, the number of buildings on the lot, and a series of building classification dummies (described in Table 2); $W_{c}$ are a series of census tract fixed effects; $I_{d t}$ are a series of dummy variables indicating the quarter and community district of the sale, which allow us to control for trends in prices within the community district; ${ }^{12}$ and $H D_{i t}$ is our vector of historic district variables. The coefficients to be estimated are $\alpha, \beta, \gamma, \delta$ and $\theta$, and $\varepsilon$ is an error term. We report standard errors clustered at the parcel level and corrected for both spatial and temporal autocorrelation.

\footnotetext{
${ }^{12}$ There are 59 community districts in New York City, but our sample is limited to the 32 community districts containing at least one lot in a historic district.
} 
Within the vector HD, we include the variable HistoricDistrictEver, which is a dummy variable that takes a value of " 1 " if the sale is located within the boundary of an area that is or will be designated as a historic district. This variable captures baseline, unmeasured differences between properties located within historic districts and comparable properties outside of them. We also include the variable HistoricDistrictPost, which takes a value of " 1 " if the sale took place inside a historic district after the district was designated by the LPC. This coefficient captures the impact of designation. Because we have sales in our dataset that predate designation by up to 40 years, we also include a dummy variable for sales that take place more than 10 years prior to designation, as we think those sales are too distant to meaningfully capture baseline, predesignation conditions. With this variable included, the counterfactual becomes the price level in the 10 years prior to designation, and the coefficient on the HistoricDistrictPost variable can be interpreted as the average difference in prices within a district after designation and prices ten years before.

The vector HD includes two continuous variables to allow the effect of the designation of historic districts to vary over time. The variable TimePost equals the number of years after the designation of a historic district that the sale took place, while the variable TimePost $S Q$ is the square of the number of years after the designation that a sale took place. The TimePost variable is coded " 0 " for sales that took place before the designation of a historic district, and for properties outside the boundaries of a historic district.

District designation is not random. The process of designation is complex, and citywide advocates play an outsized role in New York City in leading designation efforts. But property owners clearly play a role too. It is possible, for example, that property owners push for designation more vigorously when they believe that their neighborhoods are likely to appreciate. Or they might also push harder for designation when they are fearful of neighborhood decline. While we recognize that we can never fully address endogeneity concerns, we are able to examine price trends in districts prior to designation to test and control for any evident trends. We can also estimate models that use only properties that are in areas that have not yet but will become historic districts as a comparison group. To do so, we restrict sample to properties that are in areas that will become historic districts and simply test for significance of HistoricDistrictPost coefficient.

In some models, the vector HD also includes a series of dummy variables to indicate whether the property is within 250 feet of the boundary of a historic district. The variable 
BufferEver takes the value of " 1 " if the property is within 250 feet of a historic district boundary, either before or after designation. We use 250 feet as our buffer because it is about the length of one north/south block on Manhattan's gridded streets. ${ }^{13}$ As with the variables for historic districts, this variable captures baseline differences in the sales prices of properties located within buffer zones and comparable properties beyond those zones. Likewise, the variable BufferPost takes the value of " 1 " if the property sale took place within the buffer zone after the district was designated by the LPC. In Figure 2, we include maps of two historic districts - the Greenpoint Historic District in Brooklyn and the Mount Morris Historic District in Manhattan - to illustrate the construction of buffer zones around each district. In the models that include buffer zone variables, we also include continuous variables TimePostBuffer and TimePostBufferSQ that allow the spillover effects into the adjacent buffer zones to vary over time.

To test the predictions of the theory above, we examine heterogeneity across community districts by separately interacting our historic district variables with each of five indicators identifying whether a property is located in a community district that falls above the median district in the sample for development capacity or cost. Again, these indicators are: average maximum floor-area ratio, or FAR, in the community district; average unused FAR; median price per square foot for newly built housing; the dollar value of maximum FAR; and the dollar value of unused FAR.

Finally, we also run additional robustness tests. First, we run models with both a smaller and larger comparison group. To go smaller, we replace census tract fixed effects with blockgroup fixed effects. On the one hand, the blockgroup approach is appealing because it allows us to compare price appreciation of properties just inside district with the appreciation of those just outside. On the other hand, we expect properties just outside the districts to be affected by designation, so this very narrow comparison group is arguably tainted. Indeed, one could argue that even census tracts are too small. Census tracts are relatively small in New York City, especially in Manhattan, and thus the number of comparison properties that are outside the historic district but still within the same census tract is relatively small for some historic districts - and will largely comprise the buffer properties. Thus we also estimate our models with zip code fixed effects, which expand the number of comparison properties.

\footnotetext{
${ }^{13}$ We also estimated buffer models with 500 -foot buffers rather than 250 -foot buffer zones. The results were highly similar.
} 
Second, we run a series of models using the calendaring date, rather than the date of designation, as our indicator of historic district status. As noted in a previous section, calendaring occurs before the historic district is designated, but typically indicates that a neighborhood is receiving consideration for historic designation.

\section{Results}

We begin the analysis by asking how historic designation affects new construction activity in the district. Even if our primary interest lies in prices, it is important to first test whether historic designation does indeed impact redevelopment and new supply. In Table 3, the pattern of coefficients suggests that designation has a significant negative impact on the amount of new housing construction. Historic districts had less new building even before designation, which suggest the value of controlling for pre-existing levels. After designation the number of new units per year drops by about 14 in the city as a whole (column 1) and 22 in Manhattan (column 3). This represents a drop of 21 percent of a standard deviation in the outcome variable for the citywide result, and a drop of 24 percent of a standard deviation for Manhattan. Effects appear somewhat larger in the alternative specifications in which the comparison area includes parcels in bordering zones that are both outside the district and outside the buffer zone. Of course, this simple model does not answer whether the designation of districts reduced supply overall in New York City, as we do not know if the impacts we find result from construction decreasing in the district after designation or from construction actually increasing in the bordering area. At the very least, the results suggest that district designation affects decisions about where to build. Less new construction takes place in historic districts after they are designated.

Our key question is how that reduced construction affects the value of properties within and just outside of districts. The results of the first hedonic regression model are reported in Table 4, first for the citywide sample (columns 1-3) and then for Manhattan properties only (column 4). The models reported in columns 1 and 2 omit any TimePost variables. In these simple specifications, the coefficient on HistoricDistrictPost can be interpreted as the average effect of designation over the post-designation period. In model 1, this coefficient captures the average effect over the 10-year period following designation, while in model 2 this coefficient provides an estimate of the average effect over the entire post-designation period. Models 3 and 4 include TimePost and TimePost $S Q$ variables, allowing the impact to vary over time. In these 
models, the coefficient on HistoricDistrictPost can be interpreted as the change in property values that occurs immediately after designation.

The estimated coefficients on the structural variables have expected signs. Sales price per unit is significantly higher for single-family, detached homes (omitted category) than for two-family homes, condominiums, and larger apartment buildings. In addition, sales prices are higher when building and lot space is larger and when buildings include garages. The one counter-intuitive result is the coefficient on the pre-war building dummy variable, which is negative, counter to what many assume is a premium placed on pre-war buildings in New York City. This result only holds when the historic district variables are included however, suggesting the historic district variables may be capturing the premium usually associated with pre-war buildings.

After controlling for other structural characteristics, properties located in areas that are or will become historic districts sell for approximately 20 percent more than comparable properties outside those districts. This is consistent with the presence of property and community characteristics, including historic ornamentation or architectural styles, which make properties in historic neighborhoods more desirable, even absent designation.

The coefficient on HistoricDistrictPost in columns 1 and 2 suggests that designation itself also has an added, positive effect on prices of properties within a district. When examining the average effect over the ten-year period following designation (column 1), the designation of a historic district generates a 9.5 percent boost in sales prices relative to comparable properties outside the district but still in the same neighborhood. Over the entire post-designation period, the impact of designation is somewhat higher, at 14.8 percent (column 2).

When TimePost variables are added, the coefficient on HistoricDistrictPost falls in magnitude and loses significance, but the coefficient on the TimePost variable in column 3 indicates that designation leads to increases in value over time. To better understand how any designation effect evolves over time, we also estimate a more flexible model that includes a categorical indicator for each year since the district was designated. These coefficients are plotted in Figure 3, together with the trends generated from the regression coefficients in Table 4 (column 3). Panel A of Figure 3 shows that following the designation of a historic district, property values within the district rise steadily, relative to similar properties. Significantly, the pre-designation coefficients reveal no apparent trend in values prior to designation, providing no 
evidence that residents living in areas experiencing rapid appreciation (or depreciation) are more likely to request and obtain designation.

Column 4 of Table 4 shows the same model for Manhattan, and panel B of Figure 3 plots the coefficients for this Manhattan-only model. The baseline differences in price between properties in historic districts and those outside the district but in the same neighborhood are larger in Manhattan compared to the other boroughs. In Manhattan, properties located in areas that are or will become historic districts sell for 33 percent more than comparable properties outside those districts. However, the actual designation of districts appears, if anything, to have a negative effect on property values, though the coefficient on the HistoricDistrictPost coefficient is not statistically significant. We further probe this Manhattan effect in models exploring heterogeneous effects below.

Recognizing potential concerns about the endogeneity of historic district designations, we estimate a subsequent model limiting our analysis to the sample of properties located in a historic district by 2009. In this model, we use future historic districts in the borough as our comparison group. The sample includes only the 32,264 residential property transactions that occur in a historic district, either before or after the district was designated. Consistent with the previous analysis, Table 5 reports no immediate impact of historic designations on property values in the citywide sample, but finds that values quickly start to rise after the designation occurs.

To identify spillover effects into a 250 -foot buffer of historic districts, Table 6 shows the coefficients of a citywide model that includes indicators for BufferEver and BufferPost, as well as the corresponding TimePost coefficients. The coefficients on the historic district variables change only slightly compared to those displayed in Table 4, suggesting that results are not particularly sensitive to the inclusion (or exclusion) of buffer properties in the comparison group. However, results for these citywide models show that prior to designation, properties bordering historic districts sell for 3.7 or 5.5 percent less than comparable properties further from the district. This negative finding could reflect unobserved differences in structural features of property located just outside of historic districts, or lower levels of investment in those properties. In the model without TimePost controls (model 1), the actual designation of a historic district leads to an 11.9 percent increase in the average value of these bordering properties - a substantial bump for properties located just beyond the districts. When we allow impacts in the buffer area to vary over time (model 2), we see little in the way of immediate impacts, but we see rising prices over time. 
In Appendix D, we report several robustness tests for the models in Tables 4 and 6, as described in the previous section of the paper. In brief, Tables D1 and D2 show that results are very similar when we include zip code fixed effects rather than census tract fixed effects. Again, we find positive results citywide and negative impacts in Manhattan. And once again, we find that designation increases the value of properties in the buffer zones, though it takes 3-4 years to see those positive impacts in Manhattan. When we use the date of calendaring rather than designation as our date of the start of treatment, we obtain similar results, though effects are more muted and here we find an initial negative hit to property values upon calendaring, which grows more positive over time after designation (see Table D3).

\section{Heterogeneous Effects}

The model suggested that the preservation would destroy more value in areas with relatively short buildings and areas where there is robust demand for more space. We explore these implications in Table 7. The pattern of coefficients displayed in Table 7 suggests that designation has a more negative effect in neighborhoods where redevelopment would be more valuable, as hypothesized.

In New York City, the relevant issue is whether preservation limited the ability to build up, which suggested our focus on feasible additions to height, as determined by the maximum allowable floor area ratio. We find that the impact of designation on property values is more negative in community districts where the average floor-area ratio is higher and where the value of the unused development capacity is higher. In columns 1 and 2, the impact of historic designation is more negative in places with higher average maximum FAR and higher average unused FAR, signaling that the lost option of redevelopment is larger. Because property owners could build taller and more valuable buildings in these areas, the value of the foregone option to develop is greater.

Likewise, in community districts where the median price per square foot is higher or the value of the FAR - either the maximum FAR or the unused FAR - is higher, the impact of historic designation is more negative (columns 3-5). We interpret these results as reflecting the impact of fundamental demand for the neighborhood, which determines the costs of restricting more housing supply. These results are again consistent with our theoretical model suggesting that effects of designation will be more negative in areas, like Manhattan, where the lost option value of redevelopment is higher. Alternatively, in areas like Manhattan, it appears that the hit to 
land values outweighs the boost to structure values, because land values comprise such a large share of total property values (Ellen and Gedal 2012).

\section{Conclusion}

This paper sheds new light on the effects of the designation of historic districts on local housing markets, revealing that impacts vary with market conditions. Consistent with the predictions of our theory, we find that designation results in a larger increase to property values in community districts where the value of foregone development potential is lower. Also consistent with theory, the act of designating historic districts appears to offer a boost to the value of properties immediately outside the historic district. Properties located in the immediate vicinity of a district sell at a discount relative to nearby properties, but the designation of a district leads to an increase in their prices.

We cannot fully address the strong possibility that the location of preservation districts is endogenous to local conditions. The panel nature of our data does allow us to control for areaspecific mean effects and price trends. Moreover, we are reassured by the lack of any clear price trends before designation. Furthermore, the difference in the results in Manhattan and the rest of the city suggests that simple selection bias cannot explain the full story.

As for supply effects, our analysis suggests that new construction activity within districts falls after designation. Admittedly, our results do not answer whether the designation of districts reduced supply overall in New York City, as we do not know if the impacts we find result from construction decreasing in the district after designation or from construction actually increasing in the surrounding area. At the very least, the results suggest that district designation affects decisions to build.

The designation of historic districts has stirred controversy in cities across the country. Our results suggest that the designation of districts can shape the course of local housing markets, but that the effects vary across neighborhoods, consistent with our theoretical predictions. We also find some evidence of a decline in investments in the construction of buildings within historic districts over the long run. Significantly, however, our results do not capture the external benefits that historic properties provide for society as a whole. Still, as policymakers consider whether and how to preserve historic neighborhoods, our analysis underscores the need to take the particular neighborhood environment into account and to consider the long-term impact 
historic designations have on both property values and investment in housing within and just outside of the districts. 


\section{References:}

Ahlfeldt, Gabriel M. and Wolfgang Maennig. 2010. "Substitutability and Complementarity of Urban Amenities: External Effects of Built Heritage in Berlin.” Real Estate Economics 38(2):285-323.

Ahlfeldt, Gabriel M. and Alexandra Mastro. 2011. Valuing Iconic Design: Frank Lloyd Wright Architecture in Oak Park, Illinois. Working Paper from the Spatial Economics Research Center, London School of Economics.

Ahlfeldt, Gabriel M., Nancy Holman and Nicolai Wendland (2012).

"An assessment of the effects of conservation areas on value." English Heritage, London, United Kingdom. Available at ://www.english-heritage.org.uk/content/imported-docs/ae/assessment-ca-value.pdf

Asabere, Paul K., George Hachey, and Steven Grubaugh. 1989. "Architecture, Historic Zoning, and the Value of Homes." Journal of Real Estate Finance and Economics 2: 181-195.

Asabere, Paul K., and Forrest E. Huffman. 1991. "Historic Districts and Land Values." Journal of Real Estate Research 6:1-7.

Asabere, Paul K., Forrest E. Huffman, and Seyed Mehdian. 1994. "The Adverse Impacts of Local Historic Designation: The Case of Small Apartment Buildings in Philadelphia." Journal of Real Estate Finance and Economics 8:225-234.

Been, Vicki, Caitlyn Brazil, Samuel Dastrup, Ingrid Gould Ellen, John Infranca, Simon McDonnell, Max Weselcouch and Michael Williams. 2011. "State of New York City's Housing and Neighborhoods." A publication of the Furman Center for Real Estate \& Urban Policy, New York University.

Byrne, Peter J. 2012. Historic Preservation and its Cultured Despisers: Reflections on the Contemporary Role of Preservation Law in Urban Development. Georgetown Public Law and Legal Theory Research Paper No. 12-021.

Carruthers, John I., David E. Clark and Michael Tealdi. 2010. The Demand for Historic Preservation. Working Paper 2010-02, College of Business Administration, Marquette University.

Coulson, N. Edward, and Michael L. Lahr. 2005. "Gracing the Land of Elvis and Beale Street: Historic Designation and Property Values in Memphis." Real Estate Economics 33:487-507.

Coulson, N. Edward, and Robin M. Leichenko. 2001. "The Internal and External Impact of Historic Designation on Property Values." The Journal of Real Estate Finance and Economics 23:113-124.

Econsult Corp. 2010. The Economic Impact of Historic Preservation in Philadelphia. Available at http://www.preservephiladelphia.org/wp-content/uploads/Econ_Report_Final.pdf 
Ellen, Ingrid Gould, and Michael Gedal. 2012. "Valuing Urban Land: Comparing the Use of Teardown and Vacant Land Sales." Unpublished manuscript.

Ford, Deborah Ann. 1989. "The Effect of Historic District Designation on Single-Family Home Price." Real Estate Economics 17:353-362.

Glaeser, Edward L. 2010. "Preservation Follies.” City Journal 20(2).

Gilderbloom, John I., Matthew J. Hanka and Joshua D. Ambrosius. 2009. "Historic

preservation's impact on job creation, property values and environmental sustainability." Journal of Urbanism: International Research on Placemaking and Urban Sustainability 2(2): 83-101.

Heintzelman, Martin D. and Jason A. Altieri. 2011. Historic Preservation: Preserving Value? Journal of Real Estate and Economics.

The Historic Tax Credit Coalition. 2012. Third Annual Report on the Economic Impact of the Federal Historic Tax Credit. Report from the National Trust Community Investment Corporation and the Edward J. Bloustein School of Planning and Public Policy, Rutgers University.

Leichenko, Robin M., N. Edward Coulson, and David Listokin. 2001. "Historic Preservation and Residential Property Values: An Analysis of Texas Cities." Urban Studies 38:1973-1987.

Mason, Randall F. 2005. "Economics and Historic Preservation: A Guide and Review of the Literature." Published by The Brookings Institution. Available at http://www.brookings.edu/ /media/research/files/reports/2005/9/metropolitanpolicy\%20mason/2 0050926 preservation.

Mason, Randall F. 2002. "Assessing Values in Conservation Planning: Methodological Issues and Choices." Published in de la Torre, Marta, ed. Assessing the Values of Cultural Heritage. 2002. Available at http://www.getty.edu/conservation/publications_resources/pdf_publications/assessing.pdf

Mourato, Susana \& Massimiliano Mazzanti. 2002. "Economic Valuation of Cultural Heritage: Evidence and Prospects." Published in de la Torre, Marta, ed. Assessing the Values of Cultural Heritage. 2002. Available at http://www.getty.edu/conservation/publications_resources/pdf_publications/assessing.pdf

Narwold, Andrew, Jonathan Sandy, and Charles Tu. 2008. "Historic Designation and Residential Property Values." International Real Estate Review 11:83-95.

Noonan, Douglas S. 2007. "Finding an Impact of Preservation Policies: Price Effects of Historic Landmarks on Attached Homes in Chicago, 1990-1999." Economic Development Quarterly 21:17-33.

Noonan, Douglas S. and Douglas J. Krupka. 2011. "Making - or Picking - Winners: Evidence of Internal and External Price Effects in Historic Preservation Policies." Real Estate Economics 39(2): 379-407. 
Pogrebin, Robin. 2008. “An Opaque and Lengthy Road to Landmark Status.” New York Times, November 25, 2008.

Rickman, Dan S. 2009. "Neighborhood Historic Preservation Status and Housing Values in Oklahoma County, Oklahoma." Journal of Regional Analysis and Policy 39(2): 99-108.

Rose, Carol. 1981. "Preservation and Community: New Directions in the Law of Historic Preservation." Stanford Law Review 22(2):473 -XX.

Rypkema, Donovan, Caroline Cheong and Randall Mason. 2011. Measuring Economic Impacts of Historic Preservation. Available at http://www.achp.gov/docs/economic-impacts-of-historicpreservation-study.pdf

Schaeffer, Peter V., and Cecily Ahern Millerick. 1991. "The Impact of Historic District Designation on Property Values: An Empirical Study." Economic Development Quarterly 5:301312.

Stipe, Robert E. 1971. “Why Preserve Historic Resources?” Published in Legal Techniques In Historic Preservation.

Treffeisen, Alan. 2003. "The Impact of Historic Districts on Residential Property Values." New York City Independent Budget Office Background Paper, available at http://www.ibo.nyc.ny.us/iboreports/HistoricDistricts03.pdf.

Verrey, Robert and Laura Henley. 1991. "Creation Myths and Zoning Boards: Local Uses of Historic Preservation.” Published In The Politics Of Culture 94 (Brett Williams ed.).

Wood, Anthony C. 2008. Preserving New York: Winning the Right to Protect a City's Landmarks. New York City: Routledge.

Zahirovic-Herbert, Velma and Karen M. Gibler. 2012. Historic District Influence on House Prices and Marketing Duration. Journal of Real Estate Finance and Economics. 
Table 1: Descriptive Statistics of Historic Districts, by Borough and Decade

By time period of designation

\begin{tabular}{lcc|ccccc}
\hline \hline & $\begin{array}{c}\text { Total Number } \\
\text { of Districts }\end{array}$ & $\begin{array}{c}\text { Percentage of } \\
\text { Total Districts }\end{array}$ & $\begin{array}{c}1965- \\
1969\end{array}$ & $1970 \mathrm{~s}$ & $1980 \mathrm{~s}$ & $1990 \mathrm{~s}$ & $\begin{array}{c}2000- \\
2009\end{array}$ \\
\hline Manhattan & 65 & $58 \%$ & 10 & 11 & 13 & 16 & 15 \\
Brooklyn & 29 & $26 \%$ & 3 & 11 & 4 & 1 & 10 \\
Bronx & 10 & $9 \%$ & 1 & 0 & 4 & 4 & 1 \\
Queens & 6 & $5 \%$ & 1 & 0 & 0 & 2 & 3 \\
Staten Island & 3 & $3 \%$ & 0 & 0 & 1 & 1 & 1 \\
Total & 113 & $100 \%$ & 15 & 22 & 22 & 24 & 30 \\
\% of total & & & $13 \%$ & $19 \%$ & $19 \%$ & $21 \%$ & $27 \%$
\end{tabular}


Table 2: Descriptive Statistics of Residential Property Transactions, 1974-2009

\begin{tabular}{|c|c|c|}
\hline & $\begin{array}{c}\text { Properties in } \\
\text { a Historic } \\
\text { District } \\
(2009)\end{array}$ & $\begin{array}{c}\text { Properties not } \\
\text { in a Historic } \\
\text { District } \\
(2009)\end{array}$ \\
\hline \multicolumn{3}{|l|}{ Number of sales } \\
\hline Total & 32,264 & 416,290 \\
\hline Sale occurred after designation & 23,862 & - \\
\hline Sale occurred in $0-250 \mathrm{ft}$. buffer & - & 17,071 \\
\hline Lot area (sq. ft.) & 7,758 & 13,758 \\
\hline Building area (sq. ft.) & 4,043 & 2,962 \\
\hline Corner & 0.054 & 0.080 \\
\hline Irregular & 0.109 & 0.113 \\
\hline Garage & 0.045 & 0.267 \\
\hline Altered & 0.117 & 0.042 \\
\hline Building age & 75.034 & 56.431 \\
\hline Pre-War & 0.668 & 0.473 \\
\hline \multicolumn{3}{|l|}{ Building class } \\
\hline Single-family detached & 0.127 & 0.192 \\
\hline Single-family attached & 0.045 & 0.118 \\
\hline Two-family home & 0.140 & 0.211 \\
\hline Three-family home & 0.066 & 0.060 \\
\hline Four-family home & 0.041 & 0.020 \\
\hline Five/six-family home & 0.026 & 0.017 \\
\hline More than six families, no elevator & 0.040 & 0.029 \\
\hline Walk-up, units not specified & 0.082 & 0.017 \\
\hline Elevator apt bldg, coop & 0.010 & 0.003 \\
\hline Elevator apt bldg, not coop & 0.020 & 0.011 \\
\hline Loft building & 0.006 & 0.001 \\
\hline Condominium, SF attached & 0.038 & 0.008 \\
\hline Condominium, walk-up apartments & 0.020 & 0.044 \\
\hline Condominium, elevator building & 0.309 & 0.242 \\
\hline Condominium, miscellaneous & 0.004 & 0.001 \\
\hline Multi-use, single family with store & 0.005 & 0.004 \\
\hline Multi-use, two-family with store & 0.008 & 0.012 \\
\hline Multi-use, three-family with store & 0.004 & 0.003 \\
\hline Multi-use, 4+ family with store & 0.008 & 0.007 \\
\hline
\end{tabular}


Table 3: Regression of new units constructed

\begin{tabular}{|c|c|c|c|c|}
\hline & \multicolumn{2}{|c|}{ Citywide } & \multicolumn{2}{|c|}{ Manhattan } \\
\hline & (1) & (2) & (3) & (4) \\
\hline Historic District & $\begin{array}{c}-10.72812 * * * \\
(2.36517)\end{array}$ & $\begin{array}{c}-17.38417 * * * \\
(4.04731)\end{array}$ & $\begin{array}{c}-14.72305^{* * *} \\
(4.76314)\end{array}$ & $\begin{array}{c}-24.10308^{* * *} \\
(8.14536)\end{array}$ \\
\hline Post Designation & $\begin{array}{l}-1.72205 \\
(6.13506)\end{array}$ & $\begin{array}{c}3.86603 \\
(8.66425)\end{array}$ & $\begin{array}{c}-5.87514 \\
(10.90147)\end{array}$ & $\begin{array}{c}1.96504 \\
(15.40414)\end{array}$ \\
\hline Historic District*Post Designation & $\begin{array}{c}-14.37208 * * * \\
(4.35041)\end{array}$ & $\begin{array}{c}-19.96016^{* * *} \\
(7.17523)\end{array}$ & $\begin{array}{c}-22.29322 * * * \\
(7.65746)\end{array}$ & $\begin{array}{c}-30.13311^{* *} \\
(12.52748)\end{array}$ \\
\hline Buffer & & $\begin{array}{c}-13.31208^{* * *} \\
(4.23928)\end{array}$ & & $\begin{array}{c}-18.75914^{* *} \\
(8.50308)\end{array}$ \\
\hline Buffer * Post Designation & & $\begin{array}{l}-11.17737 \\
(8.03417)\end{array}$ & & $\begin{array}{l}-15.68106 \\
(13.86027)\end{array}$ \\
\hline Observations & 2,520 & 2,520 & 1,320 & 1,320 \\
\hline Adjusted $\mathrm{R}^{2}$ & 0.12208 & 0.13467 & 0.14560 & 0.16063 \\
\hline
\end{tabular}

Notes: ${ }^{* * *} \mathrm{p}<0.01,{ }^{* *} \mathrm{p}<0.05, * \mathrm{p}<0.10$. Robust standard errors. All models include area and year fixed effects. 
Table 4: Regression of sales price (log) on property characteristics, including historic designation

Citywide

\begin{tabular}{|c|c|c|c|c|}
\hline & $\begin{array}{c}\text { (1) } \\
\text { Avg. effect } \\
\text { over } 10 \text { years } \\
\text { following } \\
\text { designation }\end{array}$ & $\begin{array}{c}\text { (2) } \\
\text { Average } \\
\text { effect } \\
\text { (no cap) }\end{array}$ & $\begin{array}{c}\text { (3) } \\
\text { Impact can } \\
\text { vary with time } \\
\text { (no cap) }\end{array}$ & $\begin{array}{c}\text { (4) } \\
\text { Impact can } \\
\text { vary with } \\
\text { time (no cap) }\end{array}$ \\
\hline Historic District Ever & $\begin{array}{c}0.20649 * * * \\
(0.03426)\end{array}$ & $\begin{array}{c}0.21033 * * * \\
(0.03425)\end{array}$ & $\begin{array}{c}0.19721 * * * \\
(0.03433)\end{array}$ & $\begin{array}{c}0.32863 * * * \\
(0.04684)\end{array}$ \\
\hline Historic District Post & $\begin{array}{c}0.09543 * * * \\
(0.03530)\end{array}$ & $\begin{array}{c}0.14832 * * * \\
(0.03412)\end{array}$ & $\begin{array}{c}0.03465 \\
(0.04024)\end{array}$ & $\begin{array}{l}-0.07471 \\
(0.05585)\end{array}$ \\
\hline Time Post & & & $\begin{array}{c}0.00832 * * \\
(0.00341)\end{array}$ & $\begin{array}{c}0.00404 \\
(0.00513)\end{array}$ \\
\hline Time Post Squared & & & $\begin{array}{l}-0.00001 \\
(0.00009)\end{array}$ & $\begin{array}{l}-0.00015 \\
(0.00013)\end{array}$ \\
\hline $\log ($ Lot area $)$ & $\begin{array}{c}0.12847 * * * \\
(0.00417)\end{array}$ & $\begin{array}{c}0.12845^{* * * *} \\
(0.00412)\end{array}$ & $\begin{array}{c}0.12845^{* * *} \\
(0.00417)\end{array}$ & $\begin{array}{c}0.03376 * * * \\
(0.01174)\end{array}$ \\
\hline $\log ($ Square footage $)$ & $\begin{array}{c}0.03681 * * * \\
(0.00276)\end{array}$ & $\begin{array}{c}0.03694 * * * \\
(0.00276)\end{array}$ & $\begin{array}{c}0.03668 * * * \\
(0.00276)\end{array}$ & $\begin{array}{c}0.06896 * * * \\
(0.00557)\end{array}$ \\
\hline Corner & $\begin{array}{c}0.04767 * * * \\
(0.00381)\end{array}$ & $\begin{array}{c}0.04768 * * * \\
(0.00376)\end{array}$ & $\begin{array}{c}0.04809 * * * \\
(0.00379)\end{array}$ & $\begin{array}{c}0.06852 * * * \\
(0.02398)\end{array}$ \\
\hline Irregular & $\begin{array}{c}0.00030 \\
(0.00444)\end{array}$ & $\begin{array}{c}0.00045 \\
(0.00442)\end{array}$ & $\begin{array}{c}0.00008 \\
(0.00443)\end{array}$ & $\begin{array}{c}0.00282 \\
(0.01459)\end{array}$ \\
\hline Garage & $\begin{array}{c}0.05096^{* * * *} \\
(0.00227)\end{array}$ & $\begin{array}{c}0.05087 * * * \\
(0.00225)\end{array}$ & $\begin{array}{c}0.05094 * * * \\
(0.00226)\end{array}$ & $\begin{array}{l}0.04939 \\
(0.0929)\end{array}$ \\
\hline Altered & $\begin{array}{c}0.1891 * * * \\
(0.01059)\end{array}$ & $\begin{array}{c}0.18855^{* * * *} \\
(0.01054)\end{array}$ & $\begin{array}{c}0.18829 * * * \\
(0.01059)\end{array}$ & $\begin{array}{c}0.07602 * * * \\
(0.01685)\end{array}$ \\
\hline Number of buildings & $\begin{array}{c}-0.01214 * * * \\
(0.00173)\end{array}$ & $\begin{array}{c}0.01213 * * * \\
(0.00172)\end{array}$ & $\begin{array}{c}-0.01215^{* * *} \\
(0.00174)\end{array}$ & $\begin{array}{c}-0.24793 * * * \\
(0.03520)\end{array}$ \\
\hline Building age & $\begin{array}{c}-0.00177 * * * \\
(0.00016)\end{array}$ & $\begin{array}{c}0.00175^{* * *} \\
(0.00016)\end{array}$ & $\begin{array}{c}-0.00181 * * * \\
(0.00016)\end{array}$ & $\begin{array}{c}-0.00599 * * * \\
(0.00061)\end{array}$ \\
\hline Building age squared & $\begin{array}{c}0.00001 \\
(0.00001)\end{array}$ & $\begin{array}{c}0.00001 \\
(0.00001)\end{array}$ & $\begin{array}{l}0,00001 * \\
(0.00001)\end{array}$ & $\begin{array}{c}0.00002 * * * \\
(0.00000)\end{array}$ \\
\hline Pre-War & $\begin{array}{c}-0.04557 * * * \\
(0.00493)\end{array}$ & $\begin{array}{c}0.04567^{* * * *} \\
(0.00490)\end{array}$ & $\begin{array}{c}-0.04547 * * * \\
(0.00492)\end{array}$ & $\begin{array}{c}0.28632 * * * \\
(0.04152)\end{array}$ \\
\hline Lot area is missing & $\begin{array}{c}1.32469 * * * \\
(0.04280)\end{array}$ & $\begin{array}{c}1.32502 * * * \\
(0.04231)\end{array}$ & $\begin{array}{c}1.32343 * * * \\
(0.04277)\end{array}$ & $\begin{array}{c}0.39007 * * * \\
(0.10986)\end{array}$ \\
\hline Single-family attached & $\begin{array}{c}-0.11309 * * * \\
(0.00362)\end{array}$ & $\begin{array}{c}0.11311 * * * \\
(0.00357)\end{array}$ & $\begin{array}{c}-0.11312 * * * \\
(0.00362)\end{array}$ & $\begin{array}{c}-0.51138^{* * * *} \\
(0.03559)\end{array}$ \\
\hline Two-family home & $\begin{array}{c}-0.60271 * * * \\
(0.00283)\end{array}$ & $\begin{array}{c}0.60268 * * * \\
(0.00278)\end{array}$ & $\begin{array}{c}-0.60288 * * * \\
(0.00283)\end{array}$ & $\begin{array}{c}-0.9118 * * * \\
(0.02462)\end{array}$ \\
\hline
\end{tabular}




\begin{tabular}{|c|c|c|c|c|}
\hline Three-family home & $\begin{array}{c}-0.91665^{* * *} \\
(0.00479)\end{array}$ & $\begin{array}{c}-0.9165 * * * \\
(0.00475)\end{array}$ & $\begin{array}{c}-0.91687 * * * \\
(0.00479)\end{array}$ & $\begin{array}{c}-1.40316^{* * *} \\
(0.02976)\end{array}$ \\
\hline Four-family home & $\begin{array}{c}-1.26281 * * * \\
(0.00727)\end{array}$ & $\begin{array}{c}1.26289 * * * \\
(0.00723)\end{array}$ & $\begin{array}{c}-1.26225^{* * *} * \\
(0.00726)\end{array}$ & $\begin{array}{c}-1.70841 * * * \\
(0.03166)\end{array}$ \\
\hline Five/six-family home & $\begin{array}{c}-1.62608 * * * \\
(0.00849)\end{array}$ & $\begin{array}{c}1.62617 * * * \\
(0.00839)\end{array}$ & $\begin{array}{c}-1.62596 * * * \\
(0.00849)\end{array}$ & $\begin{array}{c}-1.90967 * * * \\
(0.03790)\end{array}$ \\
\hline More than six families, no elevator & $\begin{array}{c}-2.09907 * * * \\
(0.00944)\end{array}$ & $\begin{array}{c}2.09966 * * * \\
(0.00935)\end{array}$ & $\begin{array}{c}-2.09755^{* * *} * \\
(0.00944)\end{array}$ & $\begin{array}{c}-2.70963 * * * \\
(0.02840)\end{array}$ \\
\hline Walk-up, units not specified & $\begin{array}{c}-2.08368 * * * \\
(0.01179)\end{array}$ & $\begin{array}{c}2.08573 * * * \\
(0.01166)\end{array}$ & $\begin{array}{c}-2.0794 * * * \\
(0.01178)\end{array}$ & $\begin{array}{c}-2.6816 * * * \\
(0.02614)\end{array}$ \\
\hline Elevator apt building, coop & $\begin{array}{c}-2.14942 * * * \\
(0.03776)\end{array}$ & $\begin{array}{c}2.15069 * * * \\
(0.03784)\end{array}$ & $\begin{array}{c}-2.14597 * * * \\
(0.03775)\end{array}$ & $\begin{array}{c}-2.68549 * * * \\
(0.04590)\end{array}$ \\
\hline Elevator apt building, not coop & $\begin{array}{c}-2.24112 * * * \\
(0.01643)\end{array}$ & $\begin{array}{c}2.24204 * * * \\
(0.01620)\end{array}$ & $\begin{array}{c}-2.23949 * * * \\
(0.01642)\end{array}$ & $\begin{array}{c}-2.71191 * * * \\
(0.03512)\end{array}$ \\
\hline Loft building & $\begin{array}{c}-1.22456 * * * \\
(0.05625)\end{array}$ & $\begin{array}{c}1.22923 * * * \\
(0.05295)\end{array}$ & $\begin{array}{c}-1.21773 * * * \\
(0.05621)\end{array}$ & $\begin{array}{c}-1.72361 * * * \\
(0.06080)\end{array}$ \\
\hline Condominium, single-family attached & $\begin{array}{c}-0.69855 * * * \\
(0.02261)\end{array}$ & $\begin{array}{c}0.69802 * * * \\
(0.02250)\end{array}$ & $\begin{array}{c}-0.70048 * * * \\
(0.02261)\end{array}$ & $\begin{array}{c}-1.26238 * * * \\
(0.04654)\end{array}$ \\
\hline Condominium, walk-up apartments & $\begin{array}{c}-0.89944 * * * \\
(0.01767)\end{array}$ & $\begin{array}{c}0.89964 * * * \\
(0.01752)\end{array}$ & $\begin{array}{c}-0.90022 * * * \\
(0.01766)\end{array}$ & $\begin{array}{c}-1.66939 * * * \\
(0.05104)\end{array}$ \\
\hline Condominium, elevator building & $\begin{array}{c}-0.97651 * * * \\
(0.01731)\end{array}$ & $\begin{array}{c}0.97737 * * * \\
(0.01713)\end{array}$ & $\begin{array}{c}-0.9751 * * * \\
(0.01728)\end{array}$ & $\begin{array}{c}-1.4089 * * * \\
(0.03830)\end{array}$ \\
\hline Condominium, miscellaneous & $\begin{array}{c}-0.59131 * * * \\
(0.06046)\end{array}$ & $\begin{array}{c}0.58709 * * * \\
(0.06034)\end{array}$ & $\begin{array}{c}-0.60008 * * * \\
(0.06054)\end{array}$ & $\begin{array}{c}-0.89991 * * * \\
(0.08285)\end{array}$ \\
\hline Multi-use, single family with store & $\begin{array}{l}-0.02676^{*} \\
(0.01495)\end{array}$ & $\begin{array}{c}0.02663 * * * \\
(0.01484)\end{array}$ & $\begin{array}{l}-0.0268 * \\
(0.01494)\end{array}$ & $\begin{array}{c}-0.37516^{* * *} \\
(0.08821)\end{array}$ \\
\hline Multi-use, two-family with store & $\begin{array}{c}-0.65997 * * * \\
(0.00934)\end{array}$ & $\begin{array}{c}0.66006 * * * \\
(0.00919)\end{array}$ & $\begin{array}{c}-0.65993 * * * \\
(0.00935)\end{array}$ & $\begin{array}{c}-0.95968 * * * \\
(0.04309)\end{array}$ \\
\hline Multi-use, three-family with store & $\begin{array}{c}-1.01029 * * * \\
(0.01651)\end{array}$ & $\begin{array}{c}1.01077 * * * \\
(0.01650)\end{array}$ & $\begin{array}{c}-1.00957 * * * \\
(0.01651)\end{array}$ & $\begin{array}{c}-1.57319 * * * \\
(0.04836)\end{array}$ \\
\hline Multi-use, four or more family w/ store & $\begin{array}{c}-1.23899 * * * \\
(0.01333)\end{array}$ & $\begin{array}{c}1.23949 * * * \\
(0.01314)\end{array}$ & $\begin{array}{c}-1.23943 * * * \\
(0.01332)\end{array}$ & $\begin{array}{c}-1.89382 * * * \\
(0.03883)\end{array}$ \\
\hline Preceded designation by $10+$ years & $\begin{array}{c}-0.13511 * * * \\
(0.02995)\end{array}$ & $\begin{array}{c}0.13212 * * * \\
(0.03004)\end{array}$ & $\begin{array}{c}-0.13701 * * * \\
(0.02997)\end{array}$ & $\begin{array}{c}-0.11773 * * \\
(0.04713)\end{array}$ \\
\hline Post designation by $10+$ years & $\begin{array}{c}0.08637 * * * \\
(0.02025)\end{array}$ & & & \\
\hline Post designation by $40+$ years & $\begin{array}{c}0.16545 * * * \\
(0.05564)\end{array}$ & $\begin{array}{c}0.17387 * * * \\
(0.05598)\end{array}$ & $\begin{array}{c}0.04853 \\
(0.06534)\end{array}$ & $\begin{array}{c}0.00181 \\
(0.08854)\end{array}$ \\
\hline Constant & $\begin{array}{c}0.00000 \\
(0.00074)\end{array}$ & $\begin{array}{c}0.00000 \\
(0.00195)\end{array}$ & $\begin{array}{c}0.00000 \\
(0.00197)\end{array}$ & $\begin{array}{c}0.00000 \\
(0.00546)\end{array}$ \\
\hline Observations & 448,554 & 448,554 & 448,554 & 122,091 \\
\hline Adjusted $\mathrm{R}^{2}$ & 0.78184 & 0.78178 & 0.78214 & 0.73638 \\
\hline
\end{tabular}

Notes: $* * * \mathrm{p}<0.01, * * \mathrm{p}<0.05, * \mathrm{p}<0.10$. Standard errors correct for spatial and temporal autocorrelation. All models include Census tract and CD Quarter fixed effects. The sample is limited to arms-length sales in the 32 community districts in New York City that contained at least one lot in a historic district by 2009. 
Table 5: Regression of sales price (log) on property characteristics, limited to properties located in a historic district

\begin{tabular}{lc} 
& Citywide \\
\hline \hline & $(1)$ \\
& $\begin{array}{c}\text { Impact can } \\
\text { vary with } \\
\text { time (no } \\
\text { cap) }\end{array}$ \\
\hline Historic District Post & -0.00370 \\
Time Post & $(0.02332)$ \\
Time Post Squared & $0.01737 * * *$ \\
& $(0.00235)$ \\
& $-0.00031 * * *$ \\
& $(0.00006)$ \\
\hline Observations & 32,264 \\
Adjusted $\mathrm{R}^{2}$ & 0.66358 \\
\hline
\end{tabular}

Notes: $* * * \mathrm{p}<0.01, * * \mathrm{p}<0.05, * \mathrm{p}<0.10$. Robust standard errors (clustered by parcel). Includes full set of property level control variables (coefficients not displayed): Lot area (logged), square footage (logged), corner lot, irregular lot, garage, altered, number of buildings, building age, building age squared, pre-war building, missing lot area, and building class. The model includes borough-quarter fixed effects. 
Table 6: Regression of sales price (log) on property characteristics, including historic designation and buffer zones

Citywide

\begin{tabular}{lcc}
\hline \hline & $\begin{array}{c}(1) \\
\text { Average } \\
\text { effect } \\
\text { (no cap) }\end{array}$ & $\begin{array}{c}(2) \\
\text { Impact can } \\
\text { vary with time } \\
\text { (no cap) }\end{array}$ \\
\hline Historic District Ever & $0.22194 * * *$ & $0.19833^{* * *}$ \\
Historic District Post & $(0.01147)$ & $(0.01152)$ \\
Time Post & $0.16678^{* * *}$ & $0.04810^{* * *}$ \\
& $(0.01201)$ & $(0.01703)$ \\
Time Post Squared & & 0.00894 \\
& & $(0.00168)$ \\
Buffer variables (250 feet) & & -0.0001 \\
\hline Buffer Ever & & $(0.01670)$ \\
Buffer Post & & \\
Buffer Time Post & $\left(0.03694^{* * *}\right.$ & $-0.05496^{* * *}$ \\
& $0.11923^{* * *}$ & $(0.00989)$ \\
Buffer Time Post Squared & $(0.01029)$ & $(0.0076$ \\
& & $0.01364^{* * *}$ \\
& & $(0.00165)$ \\
Observations & & $-0.00022^{* * *}$ \\
Adjusted ${ }^{2}$ & & $(0.00004)$ \\
\hline
\end{tabular}

Notes: $* * * \mathrm{p}<0.01, * * \mathrm{p}<0.05, * \mathrm{p}<0.10$. Robust standard errors (clustered by parcel). Includes full set of property level control variables reported in Table 4 (coefficients not displayed): Lot area (logged), square footage (logged), corner lot, irregular lot, garage, altered, number of buildings, building age, building age squared, pre-war building, missing lot area, and building class. All models include Census tract and CD Quarter fixed effects. The sample is limited to arms-length sales in the 32 community districts in New York City that contained at least one lot in a historic district by 2009 . 


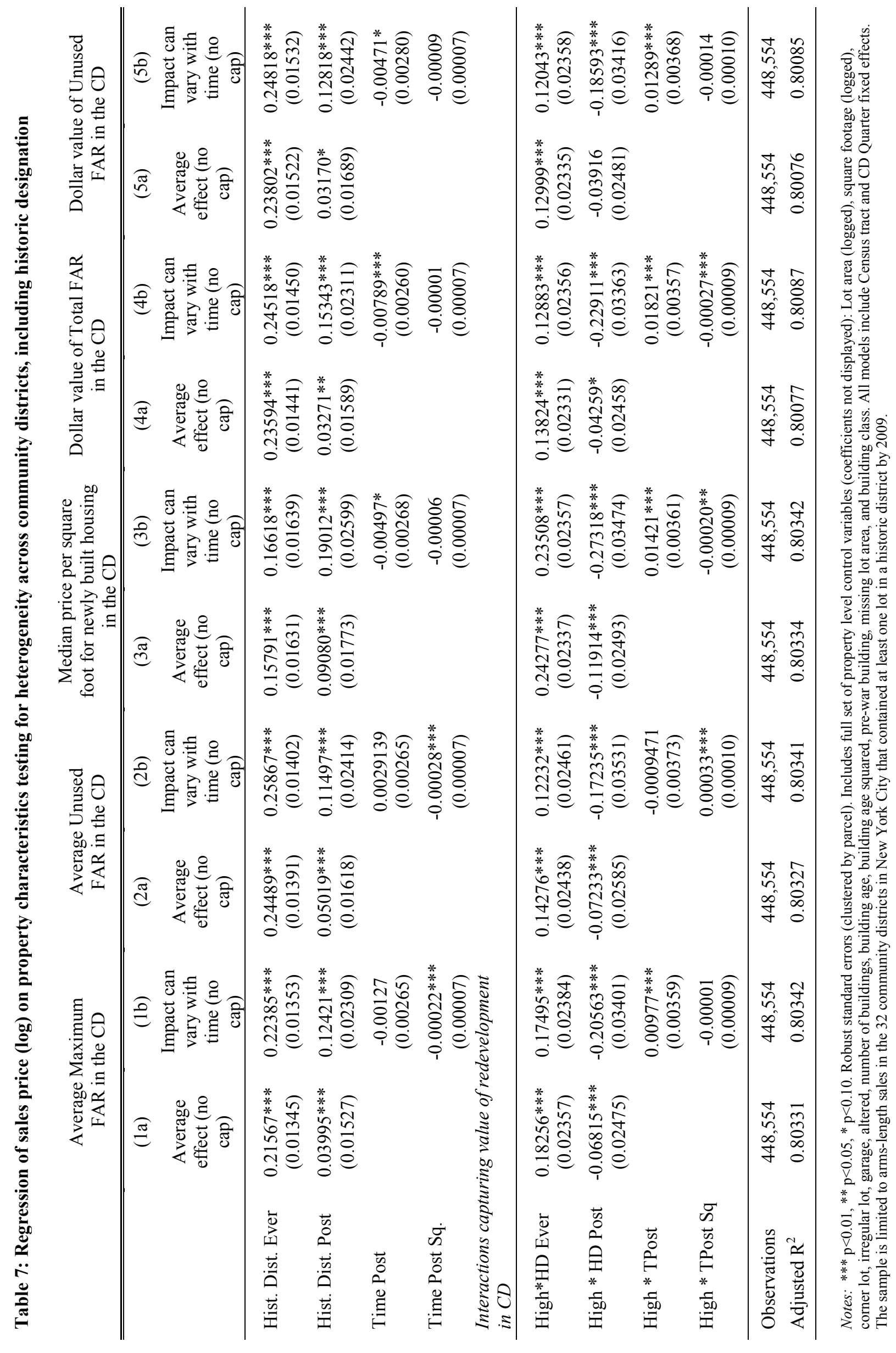


Figure 1: Redevelopment Based on Height and Architectural Quality

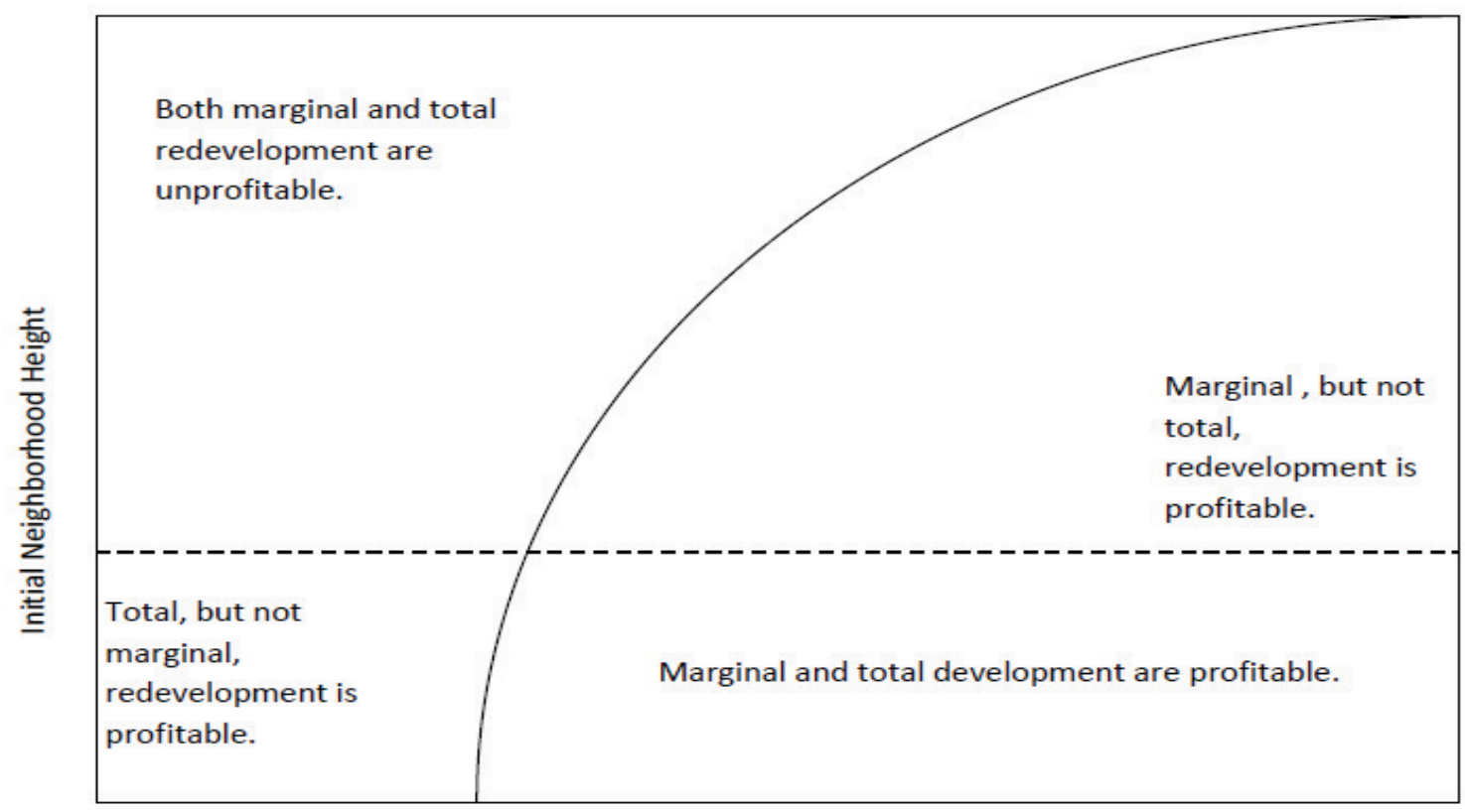

Initial Neighborhood Architectural Quality 
Figure 2: Maps of Buffer Zones, Brooklyn and Manhattan
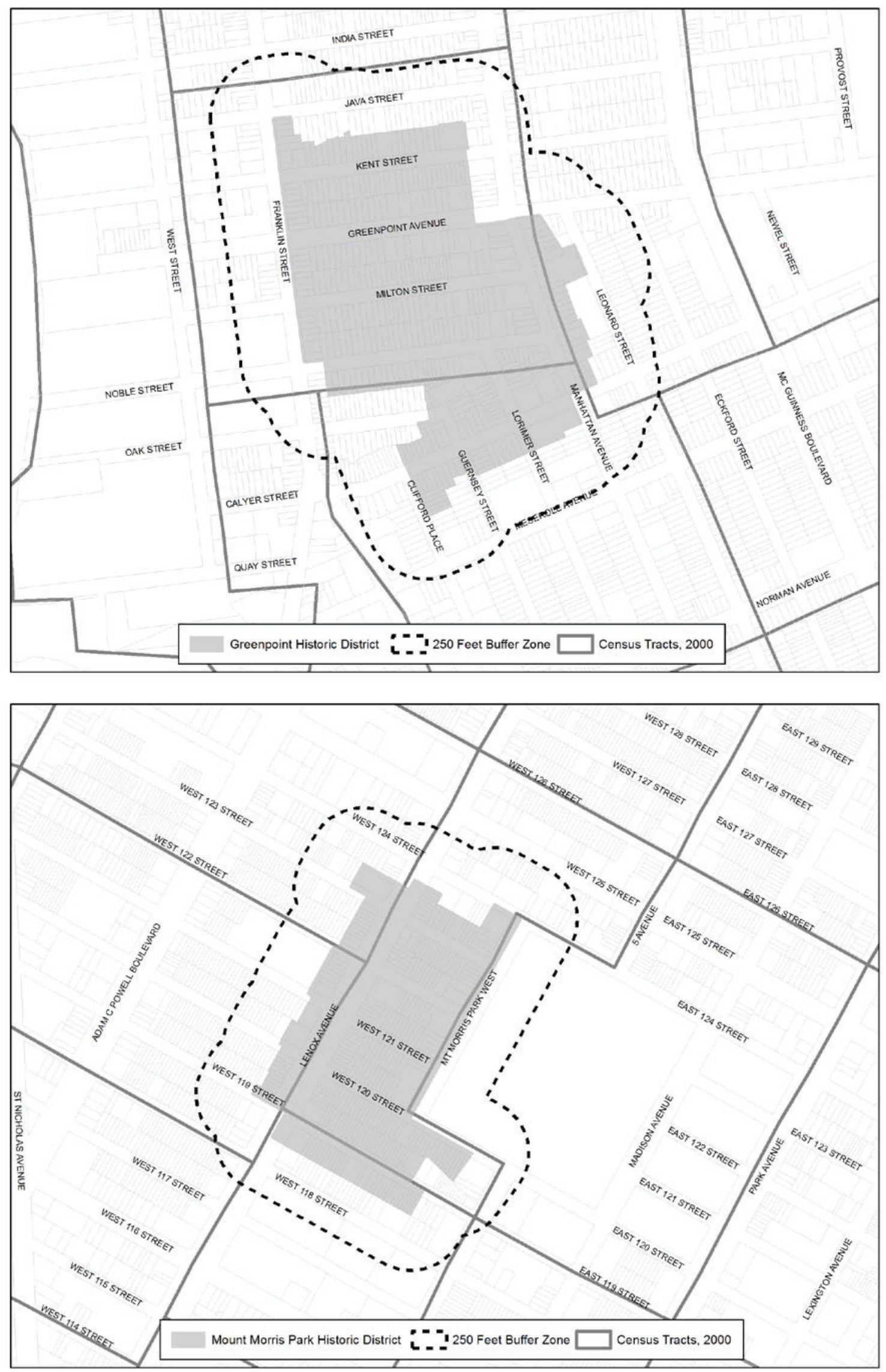
Figure 3: Regression-Adjusted Price Patterns, Before and After Designation

\section{A. Citywide}

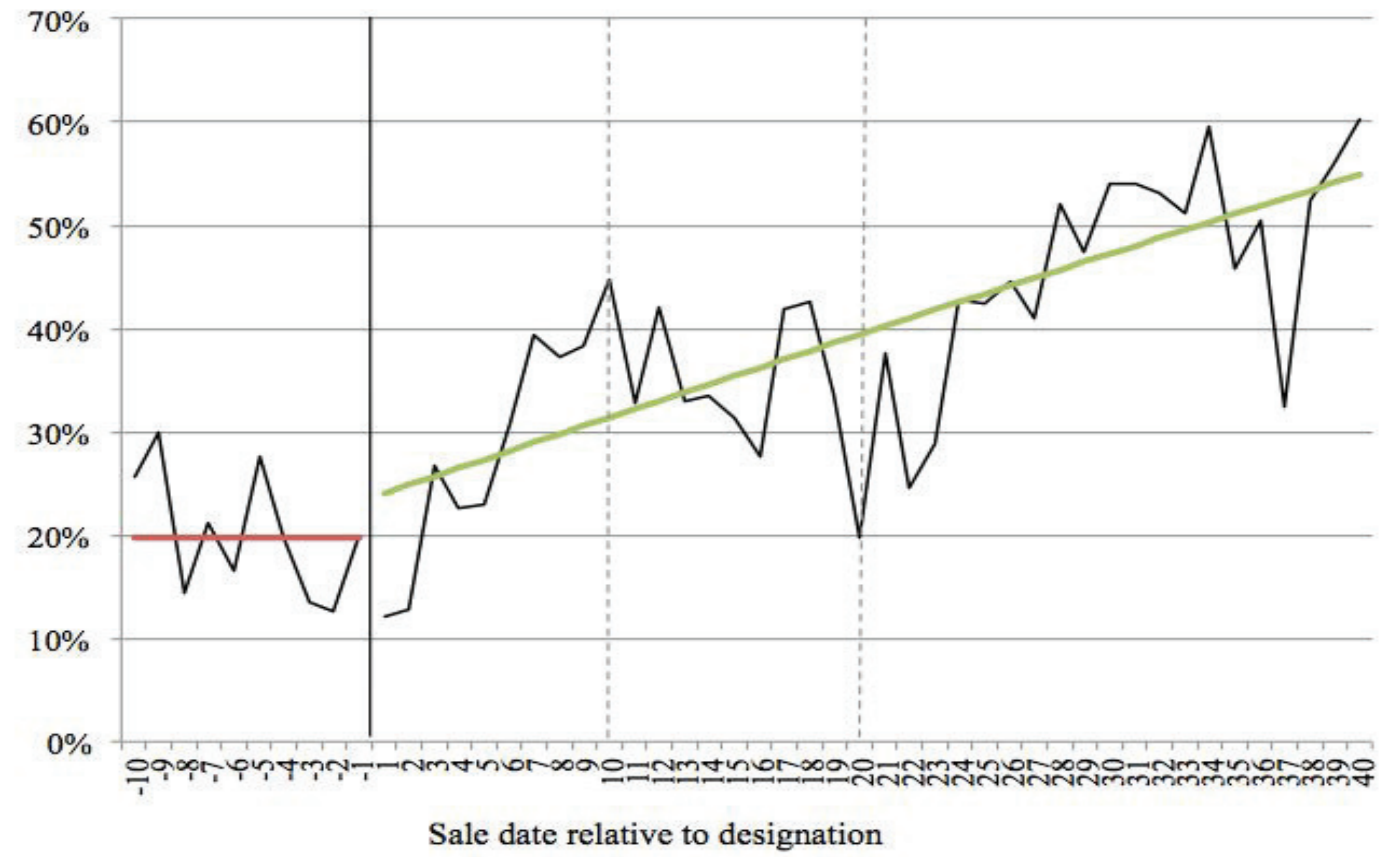

B. Manhattan

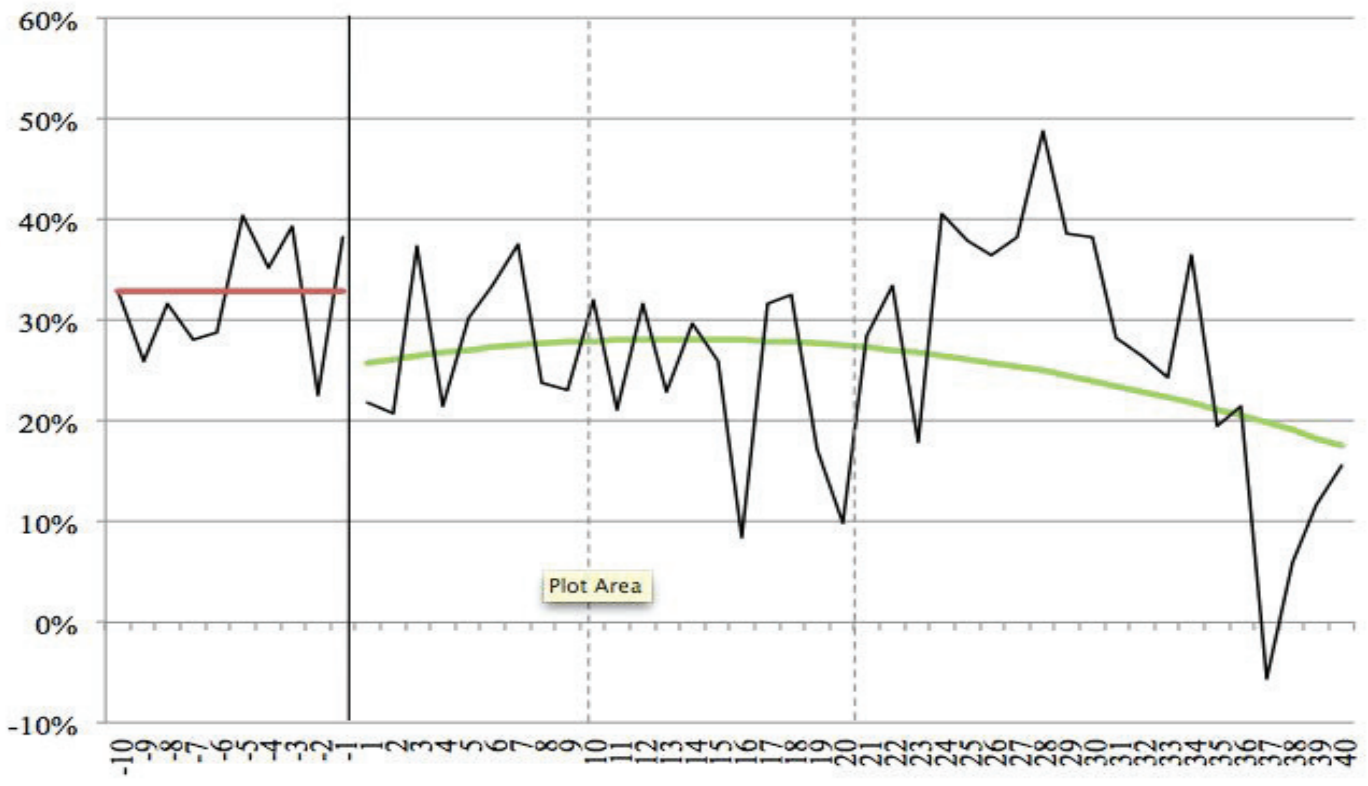

Sale date relative to designation 


\section{Appendix A: Proofs of Propositions}

\section{Proof of Lemma 1:}

Let $h_{0}^{*}$ satisfy $B+a_{0}+\delta A=c^{\prime}\left(h_{0}^{*}\right)$, while $\tilde{h}_{n}^{*}\left(\tilde{\alpha}_{n}\right)$ satisfies $B+\tilde{\alpha}_{n}+\delta A=c^{\prime}\left(\tilde{h}_{n}^{*}\left(\tilde{\alpha}_{n}\right)\right)$. The value of $h_{\max }\left(\tilde{\alpha}_{n}\right)$ satisfies $\left(B+\tilde{\alpha}_{n}+\delta A\right)\left(\tilde{h}_{n}^{*}\left(\tilde{\alpha}_{n}\right)-h_{\max }\left(\tilde{\alpha}_{n}\right)\right)=c\left(\tilde{h}_{n}^{*}\left(\tilde{\alpha}_{n}\right)\right)$, so $h_{\max }\left(\tilde{\alpha}_{n}\right)$ is rising with $\tilde{\alpha}_{n}$ and always less than $\tilde{h}_{n}^{*}\left(\tilde{\alpha}_{n}\right)$.

A mixed redevelopment equilibrium is defined by $\left(B+s_{n} \alpha_{0}+\left(1-s_{n}\right) \tilde{\alpha}_{n}+\right.$ $\delta A h * \operatorname{sn} \alpha 0+(1-s n) \alpha n-h n=c h * \operatorname{sn} \alpha 0+(1-s n) \alpha n$, and $B+s_{n} \alpha_{0}+\left(1-s_{n}\right) \tilde{\alpha}_{n}+\delta A=c^{\prime}\left(h^{*}\left(s_{n} \alpha_{0}+\left(1-s_{n}\right) \tilde{\alpha}_{n}\right)\right)$. If this exists, then profits from redevelopment are increasing with $s_{n}$ if and only if $\alpha_{0}>\tilde{\alpha}_{n}$, which suggests that a mixed strategy equilibrium is only likely to be stable if $\alpha_{0}<\tilde{\alpha}_{n}$.

Total redevelopment will be an equilibrium if and only if $\left(B+a_{0}+\delta A\right)\left(h_{0}^{*}-\tilde{h}_{n}\right)-$ $c\left(h_{0}^{*}\right)$ or $h_{0}^{*}-\frac{c\left(h_{0}^{*}\right)}{B+a_{0}+\delta A} \geq \tilde{h}_{n}$. The value of marginal redevelopment is $\left(B+\tilde{\alpha}_{n}+\right.$ $\delta A h n *(\alpha n)-h n-c h n *(\alpha n)$, where $B+\alpha n+\delta A=c^{\prime} h n *(\alpha n)$, so marginal redevelopment will occur if and only if $h_{\max }\left(\tilde{\alpha}_{n}\right)>\tilde{h}_{n}$.

If $h_{0}^{*}-\frac{c\left(h_{0}^{*}\right)}{B+a_{0}+\delta A}>\tilde{h}_{n}$, then total redevelopment is always an equilibrium. If $h_{\max }\left(\tilde{\alpha}_{n}\right)<\tilde{h}_{n}$, then no development is also an equilibrium. The value of $h_{\max }\left(\tilde{\alpha}_{n}\right)$ is greater than $h_{0}^{*}-\frac{c\left(h_{0}^{*}\right)}{B+a_{0}+\delta A}$ if and only if $\tilde{\alpha}_{n}>a_{0}$.

Hence if $\tilde{\alpha}_{n}>a_{0}, h_{\max }\left(\tilde{\alpha}_{n}\right)>h_{0}^{*}-\frac{c\left(h_{0}^{*}\right)}{B+a_{0}+\delta A}$, and some redevelopment will occur if initial heights are less than $h_{\max }\left(\tilde{\alpha}_{n}\right)$ and complete redevelopment will occur if heights are less than $h_{0}^{*}-\frac{c\left(h_{0}^{*}\right)}{B+a_{0}+\delta A}$. As the benefits from redevelopment are declining with the level of development, then there is a unique equilibrium in this range. 
If $\tilde{\alpha}_{n}<a_{0}$, then $h_{\max }\left(\tilde{\alpha}_{n}\right)<h_{0}^{*}-\frac{c\left(h_{0}^{*}\right)}{B+a_{0}+\delta A}$. If initial heights are greater than $h_{0}^{*}-$ $\frac{c\left(h_{0}^{*}\right)}{B+a_{0}+\delta A}$ then neither partial nor total redevelopment is possible, as $\widetilde{h}_{n}^{*}\left(\widetilde{\alpha}_{n}\right)-\frac{c\left(\widetilde{h}_{n}^{*}\left(\widetilde{\alpha}_{n}\right)\right)}{B+\widetilde{\alpha}_{n}+\delta A}<$ $h_{0}^{*}-\frac{c\left(h_{0}^{*}\right)}{B+a_{0}+\delta A}$. If heights are less than $h_{\max }\left(\tilde{\alpha}_{n}\right)$ then there can only be complete redevelopment, as the returns to development increase with the amount of development and initial development is remunerative. If heights are between $h_{\max }\left(\tilde{\alpha}_{n}\right)$ and $h_{0}^{*}-$ $\frac{c\left(h_{0}^{*}\right)}{B+a_{0}+\delta A}$, then there is an equilibrium in which no parcels are redeveloped, an equilibrium in which all parcels are redeveloped, and a mixed strategy equilibrium in which some parcels are redevelopment, but that equilibrium is unstable.

Proof of Proposition 1: We consider development from the perspective of a social planner attempt to maximize property values less construction costs in the across the city as a whole. We assume that there is a distribution of amenities, denoted $f(\tilde{\alpha})$, and a distribution of heights that are dependent upon amenities $g(\tilde{h} \mid \tilde{\alpha})$. Total amenities are therefore $\int_{\alpha} \int_{h}\left(\alpha_{0} s(\tilde{\alpha}, \tilde{h})+\tilde{\alpha}(1-s(\tilde{\alpha}, \tilde{h}))\right) g(\tilde{h} \mid \tilde{\alpha}) d \tilde{h} f(\tilde{\alpha}) d \tilde{\alpha}$, which we denote A. Total property values are therefore

$\int_{\alpha} \int_{h}\left(\left(B+\alpha_{0} s(\widetilde{\alpha}, \tilde{h})+\tilde{\alpha}(1-s(\widetilde{\alpha}, \tilde{h}))+\delta A\right)\left(s(\widetilde{\alpha}, \tilde{h}) h^{*}(\tilde{\alpha})+(1-s(\tilde{\alpha}, \tilde{h}) \tilde{h})-\right.\right.$ $s(\alpha, h) \operatorname{ch} *(\alpha) g h \alpha d h f(\alpha) d \alpha$.

The optimal height, conditional upon development, satisfies: $B+\alpha_{0} s(\tilde{\alpha}, \tilde{h})+$ $\tilde{\alpha}(1-s(\tilde{\alpha}, \tilde{h}))+\delta A=c^{\prime}\left(h^{*}(\tilde{\alpha})\right)$, which is the first order condition for developers as well, meaning that there is no need to regulate heights in this model.

The derivative with respect to $s(\tilde{\alpha}, \tilde{h})$ is $g(\tilde{h} \mid \tilde{\alpha}) f(\tilde{\alpha})$ times

$$
\begin{aligned}
& \left(\left(B+\alpha_{0} s(\tilde{\alpha}, \tilde{h})+\tilde{\alpha}(1-s(\tilde{\alpha}, \tilde{h}))+\delta A\right)\left(h^{*}(\tilde{\alpha})-\tilde{h}\right)-c\left(h^{*}(\tilde{\alpha})\right)\right. \\
& +\left(\alpha_{0}-\tilde{\alpha}\right)\left(s(\tilde{\alpha}, \tilde{h}) h^{*}(\tilde{\alpha})+(1-s(\tilde{\alpha}, \tilde{h}) \tilde{h})\right)+\delta\left(\alpha_{0}-\tilde{\alpha}\right) S
\end{aligned}
$$

where $\mathrm{S}$ is the total population of the city.

The second derivative is weakly positive if and only if $\alpha_{0} \geq \tilde{\alpha}$. As such, for neighborhoods which begin with a low level of amenities, it will be desirable either to 
completely redevelop or to not redevelop at all. For neighborhoods with a higher level of amenities, an interior solution is possible (although far from automatic).

When $\alpha_{0}>\tilde{\alpha}$, the condition for complete redevelopment is $\left(\left(B+\alpha_{0}+\delta A\right)\left(h_{0}^{*}-\tilde{h}\right)-\right.$ $c h 0 *+\alpha 0-\alpha h+\delta \alpha O-\alpha S>0$, or $B+\alpha 0+\delta A h 0 *-\operatorname{ch} 0 *+\delta \alpha O-\alpha S B+\alpha+\delta A>h$ implies that for any given initial amenity level there is a maximum height at which the neighborhood should be completely redeveloped, which is decrease in the initial amenity level. This height limit is unambiguously higher than $h_{0}^{*}-\frac{c\left(h_{0}^{*}\right)}{B+\widetilde{\alpha}+\delta A}$, so anytime the full development equilibrium exists when $\alpha_{0}>\tilde{\alpha}$, that equilibrium is optimal. Moreover, since even if the full redevelopment equilibrium exists, it will not necessarily occur, and because there are values of $\tilde{h}$ between $h_{0}^{*}-\frac{c\left(h_{0}^{*}\right)}{B+\widetilde{\alpha}+\delta A}$ and $\frac{\left(B+\alpha_{0}+\delta A\right) h_{0}^{*}-c\left(h_{0}^{*}\right)+\delta\left(\alpha_{0}-\widetilde{\alpha}\right) S}{B+\widetilde{\alpha}+\delta A}$, there will exist intermediate values of $\tilde{h}$ in this range at which it is optimal to subsidize the complete redevelop old neighborhoods.

When $\alpha_{0}<\tilde{\alpha}$, the relevant first derivative $\left(\left(B+\alpha_{0} s(\tilde{\alpha}, \tilde{h})+\tilde{\alpha}(1-s(\tilde{\alpha}, \tilde{h}))+\delta A\right)\left(h^{*}(\tilde{\alpha})-\tilde{h}\right)-c\left(h^{*}(\tilde{\alpha})\right)+\left(\alpha_{0}-\right.\right.$ $\alpha s \alpha, h h *(\alpha)+(1-s(\alpha, h) h+\delta \alpha O-\alpha S$, and the second derivative implies concavity. If $\frac{\left(B+\alpha_{0}+\delta A\right) h^{*}(\widetilde{\alpha})-c\left(h^{*}(\widetilde{\alpha})\right)+\delta\left(\alpha_{0}-\widetilde{\alpha}\right) S}{B+\widetilde{\alpha}+\delta A}>\tilde{h}$, then the first derivative is positive when $s(\widetilde{\alpha}, \tilde{h})$ equals zero, and some redevelopment is optimal, and that as $\tilde{\alpha}$ goes to $\alpha_{0}$ the height threshold for some redevelopment goes to $h_{0}^{*}-\frac{c\left(h_{0}^{*}\right)}{B+a_{0}+\delta A}$. The first derivative when $s(\tilde{\alpha}, \tilde{h})$ equals one is $\left(B+\alpha_{0}+\delta A\right)\left(h_{0}^{*}-\tilde{h}\right)-c\left(h_{0}^{*}\right)+\left(\alpha_{0}-\tilde{\alpha}\right) h_{0}^{*}+\delta\left(\alpha_{0}-\tilde{\alpha}\right) S$. If $\frac{\left(B+2 \alpha_{0}-\widetilde{\alpha}+\delta A\right) h_{0}^{*}-c\left(h_{0}^{*}\right)+\delta\left(\alpha_{0}-\widetilde{\alpha}\right) S}{B+\alpha_{0}+\delta A}>\tilde{h}$, then it is optimal to redevelop completely. This threshold is lower than the threshold for partial development, so that for very low levels of initial height it is optimal to redevelop completely and for intermediate levels it is optimal to redevelop partially. Only when $\alpha_{0}=\tilde{\alpha}$, the threshold for partial and total redevelopment are the same.

In this case, the threshold for optimal partial development is lower than $h_{\max }\left(\tilde{\alpha}_{n}\right)$, and the threshold for total development is less than $h_{0}^{*}-\frac{c\left(h_{0}^{*}\right)}{B+a_{0}+\delta A}$ so developers will want to 
redevelop more than they should. If partial development is the private outcome, then the level of private redevelopment is always too high relative to the social optimum.

\section{Proof of Proposition 2:}

If $\tilde{\alpha}_{n}<\alpha_{0}$, then banning redevelopment will only impact the community if development would have happened otherwise, which means that $\tilde{h}_{n}<h_{0}^{*}-\frac{c\left(h_{0}^{*}\right)}{B+a_{0}+\delta A}$. If heights are low enough so that redevelopment does occur then it will be complete, and raise unit values by $\alpha_{0}-\tilde{\alpha}_{n}$. If redevelopment is banned, the value of total real estate will fall and land values will decrease by $h_{0}^{*}\left(B+a_{0}+\delta A\right)-\tilde{h}_{n}\left(B+\tilde{\alpha}_{n}+\delta A\right)-c\left(h_{0}^{*}\right)$, which is decreasing in initial height and initial amenity levels.

If $\tilde{\alpha}_{n}>\alpha_{0}$, then banning redevelopment will only impact the community if $\tilde{h}_{n}<h_{\max }\left(\tilde{\alpha}_{n}\right)$. If $\tilde{h}_{n}<h_{0}^{*}-\frac{c\left(h_{0}^{*}\right)}{B+a_{0}+\delta A}$, then the alternative would have been total renovation. If $h_{0}^{*}-\frac{c\left(h_{0}^{*}\right)}{B+a_{0}+\delta A}<\tilde{h}_{n}<h_{\max }\left(\tilde{\alpha}_{n}\right)$, then the alternative is a mixed redevelopment equilibrium is defined by $\left(B+s_{n} \alpha_{0}+\left(1-s_{n}\right) \tilde{\alpha}_{n}+\delta A\right)\left(h^{*}\left(s_{n} \alpha_{0}+\right.\right.$ $(1-s n) \alpha n-h n=c h * s n \alpha 0+(1-s n) \alpha n$, and $B+s_{n} \alpha_{0}+\left(1-s_{n}\right) \tilde{\alpha}_{n}+\delta A=c^{\prime}\left(h^{*}\left(s_{n} \alpha_{0}+\left(1-s_{n}\right) \tilde{\alpha}_{n}\right)\right) . \quad$ In this case, the value of $s_{n}$ is rising with $\tilde{\alpha}_{n}$ and falling with $\tilde{h}_{n}$, so places with higher values of $\tilde{\alpha}_{n}$ and lower values of $\tilde{h}_{n}$, will have larger reductions in the level of redevelopment after the ban.

A ban on redevelopment will cause ex post unit prices to be increase by $s_{n}\left(\tilde{\alpha}_{n}-\right.$ $\alpha 0$, which is decreasing with $h n$, and increasing with $\alpha n$. If there is partial redevelopment, then the increase in land values from banning redevelopment equals $s_{n}\left(\tilde{\alpha}_{n}-\alpha_{0}\right) \tilde{h}_{n}$, which is again increasing with $\tilde{\alpha}_{n}$. The impact of height is initial ambiguous. If there is total redevelopment, then the change in land or total property values equals $h_{0}^{*}\left(B+a_{0}+\delta A\right)-\tilde{h}_{n}\left(B+\tilde{\alpha}_{n}+\delta A\right)-c\left(h_{0}^{*}\right)$, which is decreasing in initial height and initial amenity levels, and may be positive or negative.

\section{Proof of Proposition 3:}

In the case where the social planner can completely control the share of redevelopment, the first welfare criterion is $N_{\text {new }}\left(B(S)+\alpha_{0}+\delta A\right) \bar{h}+\int_{\alpha}\left(\left(B(S)+\alpha_{0} s(\tilde{\alpha})+\tilde{\alpha}(1-\right.\right.$ $s(\tilde{\alpha}))+\delta A)(s(\tilde{\alpha}) \bar{h}+(1-s(\tilde{\alpha}) \underline{h})-s(\tilde{\alpha}) c) f(\tilde{\alpha}) d \tilde{\alpha}$, where $A=N_{\text {new }} \alpha_{0}+$ 
$\int_{\alpha}\left(\alpha_{0} s(\tilde{\alpha})+\tilde{\alpha}(1-s(\tilde{\alpha})) f(\tilde{\alpha}) d \tilde{\alpha}\right.$ and

$S=N_{\text {new }} \bar{h}+\int_{\alpha}(s(\tilde{\alpha}) \bar{h}+(1-s(\tilde{\alpha}) \underline{h}) f(\tilde{\alpha}) d \tilde{\alpha}$. The second welfare criterion is

$N_{n e w}\left(B(S)+\alpha_{0}+\delta A\right) \bar{h}+\int_{\alpha}\left(\left(B(S)+\alpha_{0} s(\tilde{\alpha})+\tilde{\alpha}(1-s(\tilde{\alpha}))+\delta A\right)(s(\tilde{\alpha}) \bar{h}+(1-\right.$

$s(\tilde{\alpha}) \underline{h})-s(\tilde{\alpha}) c) f(\tilde{\alpha}) d \tilde{\alpha}+\int_{B_{i}=B(S)}^{\infty}\left(B_{i}-B(S)\right) q\left(B_{i}\right) d B_{i}$.

In the first case, the net benefit of allowing redevelopment in a district is

$S\left(-q(B(S))(\bar{h}-\underline{h})-\delta\left(\tilde{\alpha}-\alpha_{0}\right)\right)+(B(S)+\delta A)(\bar{h}-\underline{h})+\alpha_{0} \bar{h}-\tilde{\alpha} \underline{h}-c N_{\text {new }}$,

which is monotonically decreasing in $\tilde{\alpha}$. Hence there exists a unique value of $\tilde{\alpha}$, equal to $\frac{(B(S)+\delta A)(\bar{h}-\underline{h})-c N_{n e w}+(\bar{h}+\delta) \alpha_{0}-S q(B(S))(\bar{h}-\underline{h})}{\underline{h}+\delta S}$, below which redevelopment is allowed and above which redevelopment is not allowed. Assuming that the threshold is positive implies that the cutoff is rising with $\bar{h}$ and falling with $\underline{h}$. This cutoff point is rising with $\alpha_{0}$ and falling with $q(B(S))$ and c. In the case where the planner internalizes global welfare, there is a higher threshold equal to $\frac{(B(S)+\delta A)(\bar{h}-\underline{h})-c N_{n e w}+(\bar{h}+\delta) \alpha_{0}}{\underline{h}+\delta S}$, which is independent of $q(B(S))$ and also rising with $\bar{h}$, and $\alpha_{0}$ and falling with $\underline{h}$. In the range where $\tilde{\alpha}$ is less than $\frac{(B(S)+\delta A)(\bar{h}-\underline{h})-c N_{n e w}+(\bar{h}) \alpha_{0}}{\underline{h}+\delta S}$, total property values would be higher if the area wasn't in a historic district.

If the planner can dictate the amount of redevelopment in each area, the government $\operatorname{maximizes} N_{\text {new }}\left(B(S)+\alpha_{0}+\delta A\right) \bar{h}+\int_{\alpha}\left(\left(B(S)+\alpha_{0} s(\tilde{\alpha})+\tilde{\alpha}(1-s(\tilde{\alpha}))+\right.\right.$ $\delta A s \alpha h+(1-s(\alpha) h-s(\alpha) c f(\alpha) d \alpha$. The first order condition for redevelopment is in the case

$S\left(-q(B(S))(\bar{h}-\underline{h})-\delta\left(\tilde{\alpha}-\alpha_{0}\right)\right)+\left(B(S)+\alpha_{0} s(\tilde{\alpha})+\tilde{\alpha}(1-s(\tilde{\alpha}))+\delta A\right)(\bar{h}-\underline{h})-$ $c$ Nnew $-\alpha-\alpha 0 s \alpha h+(1-s(\alpha) h=0$ and the share of redevelopment equals $\frac{(B(S)+\widetilde{\alpha}+\delta A)(\bar{h}-\underline{h})-c N_{n e w}-\left(\widetilde{\alpha}-\alpha_{0}\right) \underline{h}-S\left(q(B(S))(\bar{h}-\underline{h})+\delta\left(\widetilde{\alpha}-\alpha_{0}\right)\right)}{2\left(\widetilde{\alpha}-\alpha_{0}\right)(\bar{h}-\underline{h})}=s(\widetilde{\alpha})$. When the government internalizes the welfare of residents, the first order condition is $\frac{(B(S)+\widetilde{\alpha}+\delta A)(\bar{h}-\underline{h})-c N_{n e w}(\underline{h}+\delta S)\left(\widetilde{\alpha}-\alpha_{0}\right)}{2\left(\widetilde{\alpha}-\alpha_{0}\right)(\bar{h}-\underline{h})}=s(\widetilde{\alpha})$, which is also weakly lower. 


\section{Appendix B: Description of the Designation Process for Historic Districts}

The responsibility for the creation of a historic district in New York City falls on the LPC, which is made up of 11 members, including at least three architects, one qualified historian, one city planner or landscape architect, one realtor, and one resident of each of the five boroughs, all of whom are appointed by the mayor for three-year terms. $^{14}$

The LPC may propose historic designation on its own accord, but often relies on the efforts of community leaders and activists to bring neighborhoods up for consideration. ${ }^{15}$ Suggestions from outside the LPC most often begin with a Request for Evaluation (RFE) filed with the LPC. ${ }^{16}$ Typically, civic organizations and community groups provide extensive supporting material along with each RFE.

When a designation proposal is submitted, the RFE Committee, which includes the Chair of the LPC along with various LPC staff members, evaluates the submission to determine whether the full LPC should consider it. ${ }^{17}$ The LPC staff documents the characteristics of the proposed district, a process that includes on-site survey, meetings with local community members, and discussions of the boundaries of the potential historic district. Because districts are required to contain only contiguous lots, the staff of the LPC must evaluate the architectural and historic quality of all the buildings within a proposed district before settling on the boundaries.

Following the evaluation by the RFE Committee, the Chair decides whether to forward the proposed designation to the full LPC. ${ }^{18}$ If so, the LPC reviews the RFE Committee's statement of the significance of the proposed district and the Committee's recommendation, along with photographs and other documentation, at a public meeting. To move the proposal forward, a majority of the Commissioners present must vote to "calendar" a proposed designation. ${ }^{19}$ Owners of the property in question are not

\footnotetext{
${ }^{14}$ N.Y.C. Charter $§ 3020(1)$, (2) (2009).

${ }^{15}$ New York City Landmarks Preservation Commission, FAQs: The Designation Process, http://www.nyc.gov/html/lpc/html/faqs/faq_designation.shtml (last visited October 13, 2011).

${ }_{16}$ An RFE is not required by law, but it is the LPC's preferred form for receiving a new request.

${ }^{17} \mathrm{Id}$.

${ }^{18}$ There is no set timeline for determining whether a proposal should be submitted to the full LPC, so proposals can remain in an indeterminate status for long periods of time (e.g., see Pogrebin 2008).

${ }_{19}$ Rules of the City of New York, Title 63, Landmarks Preservation Commission Rules 1-02, 1-01 (July 2003). Note that the meeting is not required by statute or rules to be public, but the LPC indicates that such meetings and votes are to be public. NEW YORK CITY LANDMARKS PRESERVATION COMMISSION supra note [2]. The LPC is not required to vote on calendaring every proposed designation, and each proposal is not required to go through the RFE Committee in order to be reviewed by the full LPC. Although the
} 
necessarily given notice of the meeting at which a proposed designation is calendared, however, nor is a public hearing required prior to the calendaring decision. ${ }^{20}$

While district boundaries can be modified with the same land area or reduced to a smaller land area between the dates of calendaring and designation, they cannot be enlarged. ${ }^{21}$ In principle, when the LPC calendars a proposed historic district, the Department of Buildings delays the issuance of permits for development and renovations while the LPC has the proposed district under consideration. In practice, it is not clear that the calendaring of proposed districts actually does prevent or dissuade the Department of Buildings from issuing work permits.

Once a proposal is calendared, the LPC is required to hold a public hearing, during which New York City residents, including property owners and other interested parties, are invited to offer their opinions on the proposed historic district. ${ }^{22}$ The LPC must provide notice of a planned hearing regarding a proposed designation to the City Planning Commission (CPC), the office of the borough president for the borough in which the district is located, and any affected community boards. ${ }^{23}$ Further, the LPC must publish notice of any public hearing in the City Record for the ten days preceding the hearing, and must provide notice by mail to the owner of any property in the proposed district. $^{24}$

At the public hearing, LPC staff makes a presentation about the proposed designation, and property owners and other interested parties are given an opportunity to speak. ${ }^{25}$ These parties also may submit written comments. ${ }^{26}$ No environmental review is

practice of the LPC is to consider proposals in the manner described here, the only requirement in LPC rules and the city administrative code is for a vote to calendar by a majority of the commissioners present (with a minimum of six Commissioners required for a quorum).

${ }^{20}$ Mitch Korbey, Landmarks Commission Does 30!, Herrick Zone, July 11, 2012, available at http://herrickzone.com/?p=1094\&utm_source=feedburner\&utm medium=email\&utm campaign=Feed $\% 3$ A+herrickzone $\% 2$ FXUTe $+\% 28$ HERRICK + ZONE\%29

${ }^{21}$ HistORIC DistRICTS COUNCIL, Preserving Your Historic Neighborhood: New York City Designation Process, http://www.hdc.org/preservingnyc.htm (last visited October 12, 2011).

${ }^{22}$ N.Y.C. Charter $\S 3020(7)$. See also N.Y. Admin. Code $\S 25-313$.

${ }^{23} \mathrm{Id}$.

${ }^{24}$ N.Y.C. Admin. Code $\S 25-313$ (a) (2010). Such notice must be provided by registered mail to any owner of any property at the owner's last known address as recorded by the commissioner of finance, or alternatively if no such record, by ordinary mail to the street address of the property in question. $I d$. In practice, this notice to property owners includes a copy of the designation report prepared by LPC staff. NEW YoRK CITY LANDMARKS PRESERVATION COMMISSION supra note [2].

${ }^{25}$ NeW York CiTy LandMaRKs PRESERvation COMMission supra note [2].

${ }^{26} I d$. 
required prior to the hearing, unlike the case for zoning changes. ${ }^{27}$ After a hearing, the LPC may officially designate a proposed district by a vote of at least six commissioners. ${ }^{28}$ While a proposed historic district is under consideration, the staff of the LPC completes a "designation report" outlining the boundaries of the district, and describing the historic and architectural significance of buildings within the proposed district. If the LPC ultimately designates a historic district, that designation report forms the basis of the justification for the designation. ${ }^{29}$ The designation is effective immediately upon the LPC's vote.

The LPC must then file the designation report with the City Council, the CPC and other city agencies. ${ }^{30}$ While the designation need not go through the CPC's Uniform Land Use Review Process, ${ }^{31}$ the CPC must hold a public hearing on the designation of a district and provide its own report on the designation to the City Council within 60 days. $^{32}$ The CPC report must address how the designation relates to existing zoning requirements, plans for "the development, growth, improvement or renewal" of the area, and "projected public improvements." 33 The CPC report also may recommend the action it believes the City Council should take regarding the LPC designation. ${ }^{34}$

Within 120 days of receiving the LPC's designation report, the City Council is empowered to modify or reject a proposed district. ${ }^{35}$ While the Council has rejected individual landmark designations in recent years, it has not rejected or changed any

\footnotetext{
${ }^{27}$ Korbey, supra note [].

${ }^{28}$ Landmarks Preservation Commission Rules 1-04. Note that whereas a simple majority of the commissioners present is sufficient to calendar a proposal, an absolute majority of the LPC must support a designation, regardless of the number present for the vote.

${ }^{29}$ N.Y.C. Admin. Code $\S 25-302(\mathrm{f})(1)$.

${ }^{30}$ N.Y.C. Charter $\S 3020(8)$. The designation must be filed with the CPC within 10 days of the designation action, and must also be filed with the city council, the department of buildings, the Board of Standards and Appeals, the Fire Department and the Department of Health and Mental Hygiene. N.Y.C. Admin. Code $\S$ 25-303(f). In practice the LPC provides the CPC and other city agencies with a copy of the final designation report, although this is not expressly required by statute. NEW YORK CITY LANDMARKS PRESERVATION COMMISSION supra note [2].

${ }^{31}$ Korbey, supra note []. For information about ULURP, see [].

${ }^{32}$ N.Y.C. Admin. Code $\S 25-303(\mathrm{~g})(1)$.

${ }^{33} I d$.

${ }^{34} I d$.

${ }^{35}$ N.Y.C. Charter $\S 3020(9)$, N.Y.C. Admin. Code $\S 25-303(\mathrm{~g})(2)$. A majority of the city council may either modify or "disapprove" a designation by the LPC. Id. Following a vote on such an action, the Mayor may disapprove the action of the city council within five days, in which case the city council may overrule the Mayor with the votes of two-thirds of its 51 members to reinstate the city councils disapproval (thus defeating the designation by the LPC) or modification. Id.
} 
district designations. ${ }^{36}$ The mayor may veto a modification or rejection within five days of the City Council's vote. The City Council then has ten days to over-ride the veto by a two-thirds vote.

${ }^{36}$ Pearson, Marjorie. Ibid. 


\section{Appendix C: Description of the Restrictions on Building Modifications Imposed by}

\section{Historic District Designations}

The designation of a historic district triggers a series of restrictions on building construction and modification that are likely to affect property values and sales prices in historic districts. The restrictions are described in detail in Appendix B. In brief, Any property owner in New York who wants to undertake construction work that goes beyond "ordinary repairs and maintenance" must apply for appropriate permits from the Department of Buildings (DOB) (and in some cases, other city agencies). ${ }^{37}$ If the property in question is in a historic district, the owner also must request and receive one of three determinations from the LPC: (1) a "permit for minor work," (2) a "certificate of no effect," or (3) a "certificate of appropriateness." 38 Until the LPC issues one of these notices, the Department of Buildings may not approve a building permit for construction, modification or demolition of property in a historic district, ${ }^{39}$ and the owner may not proceed with the construction or modification.

The LPC has issued guidelines delineating types of work that constitute ordinary maintenance and thus do not require LPC approval (for example, installing window airconditioning units) and work that does require LPC approval (for example, painting wood or metal cornices a different color). ${ }^{40}$ But for anything other than ordinary maintenance, even "minor work," 41 the LPC requires an owner to submit an "Application Form for Work on Designated Properties."42

The LPC forwards the Application to the DOB, which determines whether the proposed work requires a DOB building permit. ${ }^{43}$ If the project requires a building permit, the LPC will not grant a minor work permit, and instead will consider whether the work qualifies for a certificate of no effect or a certificate of appropriateness. ${ }^{44}$ If the

\footnotetext{
${ }^{37}$ See N.Y.C. Admin. Code $§ 25-302(r)$ (defining ordinary repairs and maintenance as work to "correct any deterioration or decay of or damage to such improvement or any part thereof and to restore same, as nearly as may be practicable, to its condition prior to the occurrence of such deterioration, decay or damage.")

${ }^{38}$ N.Y.C. Admin. Code $\S 25-315(\mathrm{c})$

${ }^{39}$ N.Y.C. Admin. Code $\$ 25-305(\mathrm{~b})$.

${ }^{40}$ New York City Landmarks Preservation Commission, Guidelines and Materials Checklist for Performing Work on Landmarked Buildings available at http://www.nyc.gov/html/lpc/downloads/pdf/pubs/workguide.pdf.

${ }^{41}$ N.Y.C. Admin. Code $\S 25-310(a)(1)$.

${ }^{42}$ New York City Landmarks Preservation Commission, Application Form for Work on Designated Properties available at http://www.nyc.gov/html/lpc/downloads/pdf/forms/application_form_full.pdf.

${ }^{43}$ N.Y.C. Admin. Code $\S 25-310($ b).

${ }^{44} \mathrm{Id}$.
} 
project does not require a building permit, the LPC will determine whether the proposal would "change, destroy or affect any exterior architectural feature" of property located in a historic district. ${ }^{45}$ If the proposal does not have such an effect, the LPC will grant the minor work permit. ${ }^{46}$ If the proposal would have such an effect, however, the application will be considered for a certificate of appropriateness, ${ }^{47}$

A property owner undertaking to "construct, reconstruct, alter or demolish" a building in a historic district who has applied for a permit from the DOB may use the Application Form to apply for "certificate of no effect" from the LPC in order to proceed with the project. ${ }^{48}$ In the case of an existing building, the LPC considers whether "the proposed work would change, destroy or affect any exterior architectural feature" in a historic district. ${ }^{49}$ In the case of new construction, the LPC considers whether the proposed building will "affect or not be in harmony" with the historic district. ${ }^{50}$ If there is no problematic effect, the LPC will grant the certificate of no effect. ${ }^{51}$ The LPC is required to respond to each request within 30 days after it is initially filed. ${ }^{52}$ If the certificate request is denied, there is an appeals process within the LPC, ${ }^{53}$ and if the denial is sustained the applicant may request a certificate of appropriateness. ${ }^{54}$

An owner may request a certificate of appropriateness from the LPC either when a certificate of no effect has been denied, or initially (that is, without first seeking a certificate of no effect) at the time the owner seeks a building permit. ${ }^{55}$ In evaluating a request for a certificate of appropriateness, the LPC will consider "aesthetic, historical and architectural values and significance, architectural style, design, arrangement, texture, material and color." 56 In particular, the LPC is required to take into account how the

\footnotetext{
${ }^{45}$ N.Y.C. Admin. Code $\S 25-310$ (c)(1)(a). Note also that there are particular rules regarding installation of new awnings on both residences and commercial buildings. See Rules of the City of New York, Title 63, Landmarks Preservation Commission Rules 2-12 (July 2003).

${ }^{46}$ N.Y.C. Admin. Code $\S 25-310$ (c)(2).

${ }^{47}$ N.Y.C. Admin. Code $\S 25-310(c)(1)(b)$.

${ }^{48}$ N.Y.C. Admin. Code $\S 25-306(a)(1)$.

${ }^{49} \mathrm{Id}$.

${ }^{50} I d$.

${ }^{51} I d$.

${ }^{52}$ N.Y.C. Admin. Code $\S 25-306(a)(2)$.

${ }^{53}$ Id. If the LPC does not grant the certificate of no effect, it issues a "proposed denial" of the request to the applicant, who then may file a written demand. Id. The LPC is then required to "confer with the applicant" and then is permitted 30 days to make a final determinate as to the request for certificate of no effect.

${ }_{55}^{54}$ N.Y.C. Admin. Code $\S 25-306(a)(3)$.

${ }_{56}^{55}$ N.Y.C. Admin. Code $\S 25-307$ (a).

${ }^{56}$ N.Y.C. Admin. Code $\S 25-307(\mathrm{~b})(2)$.
} 
proposed work will affect the exterior architectural features of the building, and "the relationship between the results of such work and the exterior architectural features of other, neighboring improvements" in the historic district. ${ }^{57}$ Each request for a certificate of appropriateness must be considered at a public hearing, and the LPC must make a determination regarding the request within 90 days after the request is filed. ${ }^{58}$

Beyond the LPC's certificate and permit requirements, the LPC requires that property in historic districts be kept "in good repair." "59 In particular, the LPC requires that property owners maintain and repair "all exterior portions" of buildings in historic districts, as well as all interior portions which, if not maintained, may "cause the exterior portions" to "deteriorate, decay or... fall into a state of disrepair." 60 This provision has been used by the LPC to obtain a court order requiring the property owner to undertake repairs. ${ }^{61}$

\footnotetext{
${ }^{57}$ N.Y.C. Admin. Code $\$ 25-307(b)(1)$.

${ }^{58}$ N.Y.C. Admin. Code $\$ 25-308$.

${ }^{59}$ N.Y.C. Admin. Code $\S 25-311$ (a).

${ }^{60} \mathrm{Id}$.

${ }^{61}$ City of New York v. 10-12 Cooper Square, Inc., 793 N.Y.S.2d 688, 693 (Sup. Ct. N.Y. Co. 2004) (ordering the property owner to "permanently repair and restore the exterior of the Skidmore house to a state of "good repair" in an expeditious manner" and "to maintain the Skidmore House and to keep in "good repair" all exterior portions and all interior portions which if not so maintained may cause or tend to cause the exterior portions of such improvement to deteriorate or otherwise fall into a state of disrepair.")
} 


\section{Appendix D: Robustness Results for Price Regression Models}

In Appendix D, we report the regression results from the four robustness checks for the price models. In the first, we include zip code fixed effects, rather than census tract fixed effects. This increases the number of comparison properties, as zip codes are substantially larger than census tracts in New York City. We find a positive impact of historic district designation citywide, but a negative impact when we look only at Manhattan. We then run the buffer regressions using zip code fixed effects, again reporting similar results to those with census tract fixed effects. Finally, we replicate the price analysis swapping out the date of designation for the calendaring date. Typically, the calendaring date signals the impending designation of a historic district, and we would expect the positive impact of historic districts to occur following the public announcement that the district has been placed on the calendar of the Landmarks Preservation Commission. 
Appendix Table D1: Regression of sales price (log) on property characteristics with zip code fixed effects, including historic designation

\begin{tabular}{lccc} 
& \multicolumn{2}{c}{ Citywide } & Manhattan \\
\hline \hline & $\begin{array}{c}\text { Average } \\
\text { effect } \\
\text { (no cap) }\end{array}$ & $\begin{array}{c}\text { Impact can } \\
\text { vary with } \\
\text { time (no cap) }\end{array}$ & $\begin{array}{c}\text { Impact can } \\
\text { vary with } \\
\text { time (no cap) }\end{array}$ \\
\hline Historic District Ever & $0.270569 * * *$ & $0.26983 * * *$ & $0.32223 * * *$ \\
Historic District Post & $(0.01213)$ & 0.01 & $(0.02426)$ \\
Time Post & $0.16644 * * *$ & 0.02797 & $-0.12683 * * *$ \\
Time Post Squared & $(0.01296)$ & $(0.01894)$ & $(0.03186)$ \\
& & $0.01168 * * *$ & $0.01580 * * *$ \\
& & $(0.00192)$ & $(0.00293)$ \\
Observations & & $-0.00015 * * *$ & $-0.00046 * * *$ \\
Adjusted R ${ }^{2}$ & 445,096 & 445,096 & 121,909 \\
\hline
\end{tabular}

Notes: $* * * \mathrm{p}<0.01, * * \mathrm{p}<0.05, * \mathrm{p}<0.10$. Robust standard errors (clustered by parcel). Includes full set of property level control variables (coefficients not displayed): Lot area (logged), square footage (logged), corner lot, irregular lot, garage, altered, number of buildings, building age, building age squared, pre-war building, missing lot area, and building class. All models include ZIP area and CD Quarter fixed effects. The sample is limited to arms-length sales in the 32 community districts in New York City that contained at least one lot in a historic district by 2009. 
Appendix Table D2: Regression of sales price (log) on property characteristics with zip code fixed effects, including historic designation and buffer zones

Citywide

\begin{tabular}{lcc}
\hline \hline & $(1)$ & $(2)$ \\
& $\begin{array}{c}\text { Average effect } \\
\text { (no cap) }\end{array}$ & $\begin{array}{c}\text { Impact can } \\
\text { vary with } \\
\text { time (no cap) }\end{array}$ \\
\hline Historic District Ever & $\begin{array}{c}0.28427^{* * *} \\
(0.01203)\end{array}$ & $\begin{array}{c}0.27968^{* * *} \\
(0.01206)\end{array}$ \\
Historic District Post & $0.18754^{* * *}$ & $\begin{array}{c}0.03983^{* *} \\
(0.01882)\end{array}$ \\
Time Post & $(0.01281)$ & $0.01209^{* * *}$ \\
Time Post Squared & & $(0.00192)$ \\
Buffer variables (250 feet) & & $-0.00014^{* * *}$ \\
Buffer Ever & & $(0.00005)$ \\
Buffer Post & & \\
Buffer Time Post & & $0.03428^{* * *}$ \\
Buffer Time Post Squared & $(0.01007)$ & $(0.01012)$ \\
& $0.12902^{* * *}$ & $-0.04247^{* *}$ \\
& $(0.01131)$ & $(0.01757)$ \\
Observations & & $0.01825^{* * *}$ \\
Adjusted ${ }^{2}$ & & $(0.00187)$ \\
\hline
\end{tabular}

Notes: $* * * \mathrm{p}<0.01, * * \mathrm{p}<0.05, * \mathrm{p}<0.10$. Robust standard errors (clustered by parcel). Includes full set of property level control variables (coefficients not displayed): Lot area (logged), square footage (logged), corner lot, irregular lot, garage, altered, number of buildings, building age, building age squared, pre-war building, missing lot area, and building class. All models include ZIP area and CD Quarter fixed effects. The sample is limited to arms-length sales in the 32 community districts in New York City that contained at least one lot in a historic district by 2009 . 
Appendix Table D3: Regression of sales price (log) on property characteristics with the calendaring date, including historic designation

\begin{tabular}{|c|c|c|c|}
\hline & \multicolumn{2}{|c|}{ Citywide } & \multirow{2}{*}{$\frac{\text { Manhattan }}{\text { (3) }}$} \\
\hline & (1) & (2) & \\
\hline & $\begin{array}{l}\text { Average } \\
\text { effect (no } \\
\text { cap) }\end{array}$ & $\begin{array}{c}\text { Impact can } \\
\text { vary with } \\
\text { time (no } \\
\text { cap) } \\
\end{array}$ & $\begin{array}{l}\text { Impact can } \\
\text { vary with } \\
\text { time (no } \\
\text { cap) }\end{array}$ \\
\hline Historic District Ever & $\begin{array}{c}0.27461 * * * \\
(0.01282)\end{array}$ & $\begin{array}{c}0.27493 * * \\
(0.01313)\end{array}$ & $\begin{array}{c}0.39549 * * * \\
(0.02761)\end{array}$ \\
\hline Cal Historic District Post & $\begin{array}{c}0.06409^{* * *} \\
(0.01359)\end{array}$ & $\begin{array}{c}-0.04064^{* *} \\
(0.01689)\end{array}$ & $\begin{array}{c}-0.15513 * * * \\
(0.03487)\end{array}$ \\
\hline Time Post & & $\begin{array}{c}0.00452 * * * \\
(0.00079)\end{array}$ & $\begin{array}{c}0.00628^{* * *} * \\
(0.00192)\end{array}$ \\
\hline Cal Time Post Squared & & $\begin{array}{c}0.00006 * * * \\
(0.00002)\end{array}$ & $\begin{array}{c}-0.00020^{* * *} \\
(0.00005)\end{array}$ \\
\hline Observations & 448,554 & 448,554 & 122,091 \\
\hline Adjusted $\mathrm{R}^{2}$ & 0.78167 & 0.78187 & 0.73645 \\
\hline
\end{tabular}

Notes: $* * * \mathrm{p}<0.01, * * \mathrm{p}<0.05, * \mathrm{p}<0.10$. Robust standard errors (clustered by parcel). Includes full set of property level control variables (coefficients not displayed): Lot area (logged), square footage (logged), corner lot, irregular lot, garage, altered, number of buildings, building age, building age squared, pre-war building, missing lot area, and building class. All models include Census tract and CD Quarter fixed effects. The sample is limited to arms-length sales in the 32 community districts in New York City that contained at least one lot in a historic district by 2009. 